Portland State University

PDXScholar

$5-22-1987$

\title{
American Foreign Policy: The Utility of Force as an Influence, Bargaining, or Coercive Force in the Caribbean Basin
}

Susan M. Marandas

Portland State University

Follow this and additional works at: https://pdxscholar.library.pdx.edu/open_access_etds

Part of the Caribbean Languages and Societies Commons, and the International Relations Commons Let us know how access to this document benefits you.

Recommended Citation

Marandas, Susan M., "American Foreign Policy: The Utility of Force as an Influence, Bargaining, or Coercive Force in the Caribbean Basin" (1987). Dissertations and Theses. Paper 3722.

https://doi.org/10.15760/etd.5606

This Thesis is brought to you for free and open access. It has been accepted for inclusion in Dissertations and Theses by an authorized administrator of PDXScholar. Please contact us if we can make this document more accessible: pdxscholar@pdx.edu. 
AN ABSTRACT OF THE THESIS OF Susan M. Marandas for the Master of Arts in Political Science presented May 22, 1987.

Title: The Utility of Force as an Influence, Bargaining or Coercive Force in the Caribbean Basin

APROVED BY MEMBERS OF THE THESIS COMMITTEE:

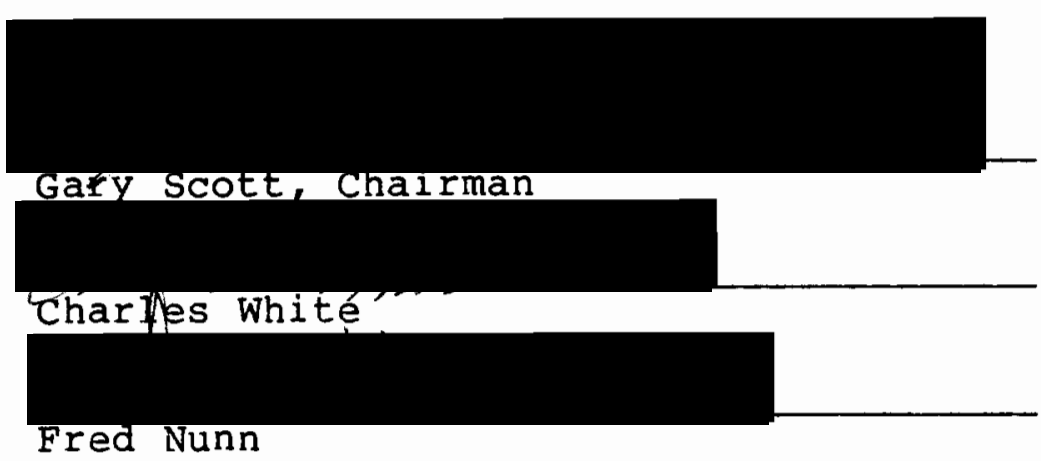

Throughout history states have pursued both cooperative and power-oriented strategies. Moralists and realists have long questioned the appropriateness of using force to gain state objectives. Recent analysts have stressed that states have a moral duty to manage international uncertainty in the best interests of their citizens. While this might involve utilizing both power-seeking and order-seeking strategies, it has been suggested that pursuing order-seeking strategies could help alleviate international uncertainty. 
An historical survey, as well as recent case studies in Grenada and Nicaragua, indicate that the United States often has relied upon military strategies in the caribbean Basin. The United States has employed a variety of techniques including "shows-of-force," threats, coercive diplomacy, intervention, and covert activities. These policies appear to have been based upon the assumption that military policies can be carefully calculated to alter the behavior of another state. Due to classified information, sensitive information is often restricted regarding this topic. However, available information indicates that American foreign policy regarding the use of force in the Caribbean Basin has not been useful.

While such policies may appear to have been successful in the short run, the same policies often have brought negative repercussions in the long run. Not only has the United States been regarded unfavorably, but it has been portrayed as a nation which only observes international law when it is convenient to do so. Further, international uncertainty has often been exacerbated by U.S. actions. Also, it is not clear that such military strategies always have been carefully designed; and even if they were, such policies would not be completely predictable. The United States needs to design new foreign policy strategies, relying less upon military force. 


\title{
AMERICAN FOREIGN POLICY \\ THE UTILITY OF FORCE
}

AS

AN INFLUENCE, BARGAINING, OR COERCIVE FORCE

IN

THE CARIBBEAN BASIN

by

SUSAN M. MARANDAS

A thesis submitted in partial fulfillment of the requirements for the degree of

\author{
MASTER OF ARTS \\ in \\ POLITICAL SCIENCE
}

Portland State University

1987 
TO THE OFFICE OF GRADUATE STUDIES AND RESEARCH:

The members of the Committee approve the thesis of Susan M. Marandas presented May 22, 1987.

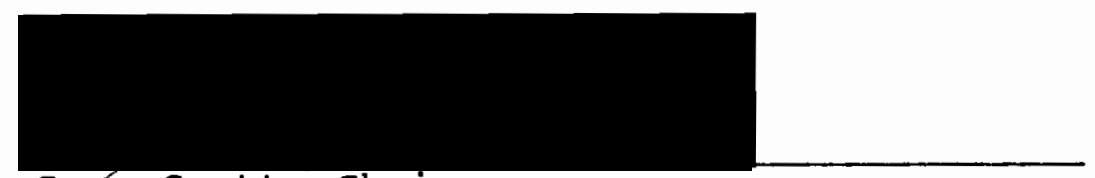

Gary Scott, Chairman

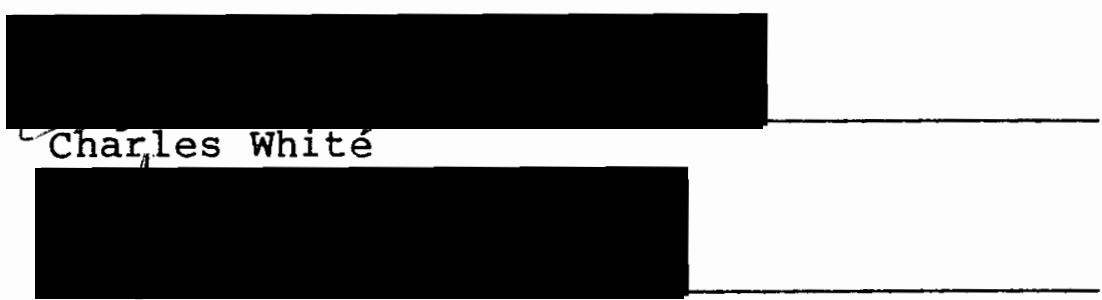

Fred Nunn

\section{APPROVED :}

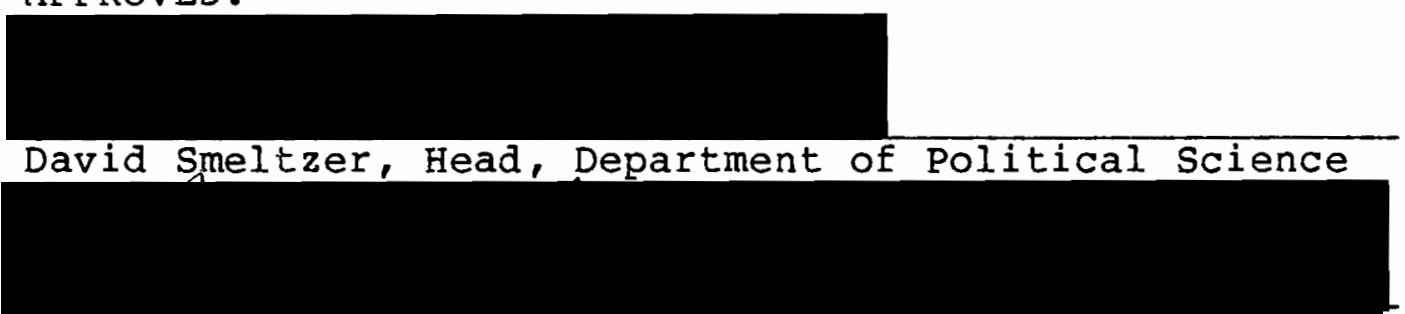

Bernard Ross, Dean of Graduate studies and Research 
You must know there are two ways of contesting, the one by the law, the other by force...because the first is frequently not sufficient, it is necessary to have recourse to the second. Niccolo Machiavelli, The Prince

An international order cannot be based on power alone for the simple reason that mankind will in the long run always revolt against naked power. An international order presupposes a substantial measure of general consent.

E. H. Carr, The Twenty Years' Crisis 
TABLE OF CONTENTS

I THE UTILITY OF FORCE. . . . . . . . . . . I 1

Reexamination of Historical Assumptions . 4

Need and Utility

Strategy of Force

Moralist and Realist Arguments

Reexamination of Recent Assumptions . . 6

Need and Utility Reconsidered

Revised Strategy of Force

Moralist and Realist Arguments

New Conceptualizations

Need for Further Reexamination

Endnotes. . . . . . . . . . . 14

II EXAMINATION OF U.S. FOREIGN POLICIES AND THE USE OF FORCE IN THE CARIBBEAN BASIN . . . . 18

Early Sources of the Region's Problems. - 19 U.S. Responses to the Region's Problems . 20

Ad Hoc Responses

U.S. Early Involvement

Temporary Restraints

World War II and Strategic Imperatives

Cold War Influences

Vietnam Influence

Alternatives to Force in the

Caribbean Basin

Conservative Comeback

Endnotes. . . . . . . . . 57

III GRENADA AND U.S. POLICIES . . . . . . . . 66

Political Background. . . . . . . . 66

U.S. Policy Responses... . . . . 69 
Evaluation of U.S. Strategies . . . . 73

Endnotes. . . . . . . . . . 79

IV NICARAGUA AND U.S. POLICIES ... . . . . 81

Political Background and Early

U.S. Responses. . . . . . . . . 82

Early Foreign Intervention

The Seeds of Revolution

Carter's Response

Reagan and the Attempted Communist

Rollback. . . . . . . . . . . 88

Early Reagan Policies

Evaluation of Early Policies

Reagan and the Mining of the Nicaraguan

Harbors .............. 106

The Course of Events

The ICJ Judgment

Evaluation of the U.S. Actions

Increase in system Instability

The United States as a Villain

Overall Evaluation of U.S. Strategies . . 127

Endnotes. . . . . . . . . . . 131

$\mathrm{V}$ CONCLUSION AND RECOMMENDATIONS. . . . . . 140

Generalizations . . . . . . . . 140

Inferences. . . . . . . . . . . 142

First Impressions

Further Analysis

Assumptions Challenged. . . . . . . 145

Assumption \#1

Assumption \#2

Recommendations . . . . . . . . 148

Endnotes. . . . . . . . . . 150 
CHAPTER I

THE UTILITY OF FORCE

In spite of pronouncements regarding the necessity for international law and order, the United States as well as other nations have continued to rely upon force in the international arena. Incidents in the 1980s, as in the Falklands, Grenada, Lebanon, Libya, and Nicaragua reveal that violence and the threat of violence have remained as state strategies in international politics. Such calculated plans have represented attempts "to influence the course of international developments in a desired manner." 1

However, the unpredictability of both the international environment and of the military strategies make it imperative to reexamine the assumptions regarding the necessity for force as well as the utility of present military policies. Questions--ranging from moral objections to pragmatic considerations--have arisen regarding the appropriateness of using force to obtain state objectives. An overview of U.S. military strategies in the Caribbean Basin with emphasis on the Nicaraguan situation reveals the problems of the U.S. military policies, both from a pragmatic and moral or philosophical point of view; furthermore, such a 
study reveals the need to develop alternatives to military strategies.

\section{REEXAMINATION OF HISTORICAL ASSUMPTIONS}

Need and Utility

There have been times the need and utility of military force have been questioned. During such periods states have attempted to maintain peaceful international relations with each other. For example, in 1814-1815, after the era of Napoleon, the Congress of Vienna attempted to formulate treaties that would create a more stable order in Europe. And, the Holy Alliance, by stressing the value of a ruler acting as a Christian toward his subjects and other rulers, also attempted to create a more positive international environment.

However, in spite of efforts at cooperation, states have often resorted to force to achieve their goals. As Machiavelli pointed out, if lawful behaviors do not achieve desired goals, it may be necessary for the state to employ force. 2 And E. H. Carr has emphasized that in the early nineteenth century Rarl Maria von clausewitz, attempting to advance Prussian interests, emphasized the legitimacy of force by stating: "...war is nothing but the continuation of political relations by other means." 3 As characterized by ziegler, Bismarck followed clausewitz's dictum "that war is a useful instrument of policy" and believed that: 
"...it is not by speeches and resolutions that the great questions of the time are decided...but by iron and blood."4 Bismarck's successful military experiences with Prussia and the unification of Germany reinforced the idea that war is a useful policy. Prussian battle deaths were low in comparison to the enemy; and the wars did not seem disruptive to the economic and political structure in the home country because the wars were so rapid. 5

\section{Strategy of Force}

Methods of force and concepts regarding its use have also varied during historical periods. While force has undoubtedly been used at times as a threat, force often has been associated with war, with brute force being used to achieve specific goals. States have used forceful methods to acquire territory, to create or consolidate a political order, to defeat an enemy, or to acquire position or wealth in the international system--above all, force was used because "states expected to benefit from its use and from the new distributions they expected after it had been used." 6

Moralist and Realist Arquments

Viewpoints regarding the appropriateness of force have been most often presented from a moralist or realist perspective. Certain broad concepts have tended over time to characterize these terms. 
Moralists have argued that forceful acts need to be judged in accordance with higher religious or moral law. 7 Like individuals, states are expected to comply with this higher standard. Moralists believe that cooperation and observance of international law will facilitate this compliance and promote order and peace within the international community. Moralists recognize that states and their rulers do not behave according to moral standards, but they believe "they ought to do so" and that it is the duty of leaders to create an international environment in which they will achieve this aim. ${ }^{8}$ The moralist position can be further refined by differentiating between a moral, or ethical perfectionist, and a non-perfectionist moralist. According to Arnold Wolfers a moral perfectionist would consider whether the end justifies the means and would conclude that "no matter how noble and virtuous the end, it never justifies the use of means that violate moral/ethical standards." 9 However, a non-perfectionist moralist would judge an act upon both the ethical standard of behavior and upon the specific context within which the act is performed. 10 Therefore, a non-perfectionist moralist would agree "in condoning the acts of those who kill in self-defense." 11

Rather than asking whether policies are in accord with abstract moral principles, realists would evaluate a policy by its political consequences. 12 In particular, realists 
would consider how a policy would affect the power of the nation. Realists stress that no state recognizes an authority higher than itself, and there is no international agency capable of maintaining order. This results in an anarchic international environment which is characterized by insecure state relationships. It has been argued that states not only fear losing their national sovereignty and territorial boundaries in such an environment, but that states often deliberately seek to increase their power in such a situation. In such an anarchic environment, it has been suggested by moralists that states need to make policies which will protect their national sovereignty and territory. However, realists have not considered states to be bound by the same moral principles as individuals. In fact, according to Morgenthau "...the state has no right to let its moral disapprobation...get in the way of successful political action."13 E.H. Carr has agreed: "In the international order, the role of power is greater and that of morality less."14 To these realists the criterion to be applied in choosing methods is not their morality but rather their effeciency. 15 However, some realists still feel obliged to respect the moral standards of others, for they realize that to be completely ruthless can create strong opposition and set back their cause. 16 


\section{REEXAMINATION OF RECENT ASSUMPTIONS}

Need and Utility Reconsidered

As in other historical periods, states in the twentieth century have sought to emphasize cooperation in the international environment. The League of Nations, the United Nations, the emphasis on international law, and the continued theorizing concerning possible philosophical/moral approaches to foreign policy all testify to the search for more peaceful approaches to international relations.

Yet, in the twentieth century the threat or use of violence has circumscribed international politics. It can be argued that international law actually legitimizes military force by such concepts as sovereignty, self-help, selfdefense or retaliation. The World Wars, Korean and Vietnam wars are not only examples of violence, but unlike Bismarck's Prussian victories, they have proven to be disruptive, lengthy, and costly. 17 The threat of nuclear destruction has also affected attitudes regarding the usefulness of force. While it can be argued that it would be possible to survive (or even "win") a nuclear war, the dangers of using nuclear weapons also has been emphasized. The employment of advanced military capabilities has come to be regarded as self-destructive; the fear exists that even limited violence could escalate. Still, threats and military confrontations continue. 
In the 1980 s the world has experienced a remilitarization of international relations, with an emphasis on the use of limited physical coercion as a means of achieving objectives. ${ }^{18}$ Repeated reliance upon military strategies in Nicaragua, Grenada, and Libya illustrate the perception that the application of limited military force is useful to achieve goals. And the Soviet actions in Afghanistan are an indication that other powers are employing military strategies in attempting to achieve their goals also.

Revised Strategy of Force

In historical periods, force often had been associated with brute force or war, but in recent years it has been argued that "plain war has now been replaced" by a more refined use of force. ${ }^{19}$ Limited force has become regarded as a projection of state power to establish and maintain control over other states. 20 In particular, limited force has become viewed as a method to control other states by affecting their attitudes, expectations, and resolve. 21

Therefore, the military power of a country is not only measured by its destructive capability, but by its capacity to influence the behavior of another country. A limited military action can be viewed as a technique of influence, as a means to political objectives, with states being affected by the threat of force. The strategy of using or threatening force is based on the assumption that the opponent state will alter its behavior (if force can alter it at all) because it 
fears or expects more violence will be used against it if it does not alter its behavior. 22

A whole range of policies has been devised based upon the assumption that limited violence is useful to project state power to alter the behavior of other states. In devising these plans, the term strategy has come to be used interchangeably with the term policy. 23 specifically, strategies can be defined as "the art of distributing and applying military means to fulfill the ends of policy."24 The term strategy also implies that a state's military policies represent "calculated, coherent plans" designed "to influence the course of international developments in a desired manner."25 Such influence strategies include displays or shows of force, military force specifically designed to communicate, influence or coerce, as well as actual use of mlitary force, as in interventions. Also, if economic pressure, propaganda, subversion and diplomacy are combined with force, then they too may be considered as strategic policies. 26 Another form of strategic policymaking has been referred to as "coercive diplomacy." Coercive diplomacy refers to a situation where force has been used specifically as a method of communication to induce the opponent to revise his calculations or behavior. 27

In recent years, there has been a shift in emphasis regarding the usefulness and strategies of force. ${ }^{28}$ While nuclear war may be feared, limited war and threats of war can 
be viewed " as techniques of influence, not of destruction; of coercion and deterrence, not of conquest and defense; of bargaining and intimidation." 29 Military action, then, would not be viewed as an alternative to bargaining, but as a process of communication, influence, bargaining, and coercion.

\section{Moralist and Realist Arquments}

There is still controversy between those who are regarded as moralists and realists. However, recent theorizing has further refined conceptual thinking regarding this topic. Recent political analysts have argued that the moralist-realist framework is no longer adequate, that its dichotomy of views which polarize power and cooperation has over-simplified matters.

New Conceptualizations

A recent criticism has been directed at the realist emphasis upon competition and power-seeking as the main motivation of state behavior. ${ }^{30}$ Recent work by snidal has emphasized that there is a basic flaw in the realist emphasis upon the state as a power-seeking actor. Rather, both competition and cooperation should be considered as an integral aspect of state behavior. States will collaborate when it is in their interest to do so. States do not just act in their own immediate self-interest, but are guided by the concept of "strategic rationality." This philosophy 
takes into account the possible reactions of other states, as well as the pursuit of immediate state interests. Specifically, taking into consideration the long term reactions of other states could act as a modifying effect upon state behavior; the incentive not to cooperate on a given issue would be mitigated by the fear that non-cooperation by one state would lead to later, non-cooperative behavior by other states. If policies are devised from the viewpoint of this "strategic rationality" a more cooperative pattern of interaction could replace the traditional anarchic aspect of the international scene.

Other analysts have also argued that analyzing international relations from a moralistic-realist perspective is inadequate. Scott and Carr have argued that the state is not subject to moral principles while involved in policymaking. 31 Therefore, in evaluating foreign policy actions, "it is something of a category mistake to think that the principles of a universal ethic are relevant to foreign policy making." 32 However, the state must conduct policymaking in an anarchical international environment. Due to this situation, the state does have "a moral obligation to their own citizenry." 33 specifically, the state has the duty to manage international uncertainty for its citizens. A state will be more successful in accomplishing this aim by adopting a policy which makes selective use of both power-seeking and order-seeking policies. Power-seeking 
policies continue to be used because: "Order-seeking strategies cannot overcome the dilemma of international distrust." 34 Further, given the state of the international environment, it would be unrealistic to expect or even "hope for the worldwide emergence of brotherly love." 35 Yet, while state reliance upon its own power may seem to ensure its security from the threat of other states, power-seeking may exacerbate the very problem it is attempting to manage. Power-seeking by one state may increase power-seeking strategies in other states. ${ }^{36}$ Therefore, states need to be guided by the concept of "strategic consequentialism."

Following such a concept would mean that "power-seeking and order-seeking moves would be strategically selected according to their likely consequences for the security and well-being of the state (its citizens) initiating the action." 37 In order for policies to be effective, a wide range of options must be considered; and strategies need to be calcuated and recalculated to be certain the desired effect is sustained. It is necessary for the state to know "when a power-seeking or an order-seeking strategy will pay the greatest dividends on any particular issue." 38 Further, failure to utilize a "strategic- consequentialist" approach would imply that many policy options actually would not be considered, or that options might have been circumvented by premature actions. $^{39}$ To develop truly useful policies, the state must be aware of the possible ramifications of many 
strategies, as well as the effect of various state actions upon other states within the international system. Only if a state follows such an approach can the state develop successful strategies and effectively represent its citizens.

Recent analysts would argue, then, that force ought to be avoided if possible, but that various situations may warrant or even necessitate the use of force. This does not mean that force is advocated. In fact, avoiding violence in the international arena could serve both moral and pragmatic purposes. Also, these analysts warn that gains incurred by force in the short run can cause problems in the foreseeable future. While resolution of a problem by force might seem to affect the opponent state only, in the long run all states will be affected by an arbitrary and unstable inernational system.

\section{Need for Further Reexamination}

Recent theorizing suggests that older conceptual frameworks are inadequate and that further investigation of "strategic rationality" or "strategic consequentialism" would be beneficial to understand the working of the international system, and of the U.S. role within that system. As noted, it is only by analysis and recalculation that effective state policies can be devised for the benefit of that state's citizens.

An examination of U.S. policies in the Caribbean Basin is particularly useful for evaluating military policies, 
since the United States has relied upon military strategies so often in this area. Also, viewing U.S. policies in the Caribbean Basin allows military strategies to be analyzed from a broad perspective. Policies can be evaluated in relationship to their effect upon specific states, to the whole region, and from the region to the entire international system. Local, regional, and global contexts are all important. 40 Emphasis upon a broad setting also helps to emphasize that states are actors which are part of an international arena, an environment providing various constraints on state actions. While the United states may have the military power to influence states to achieve short-term goals, an examination of such policies may indicate that military strategies may not be in the long-run best interest of the United States. 
ENDNOTES

${ }^{1}$ Peter Bernholz, The International Game of Power (Berlen: Mouton, 1985) p. 15.

${ }^{2}$ Niccolo Machiavelli, The Prince, trans. W.R. Marriott (London: J.M. Dent and Sons, 1908) p. 97.

${ }^{3}$ E.H. Carr, "Military Power," in The Theory and Practice of International Relations, 2nd ed. Eds. Fred A. Sondermann, William C. Olson and David S. McLellan (Englewood Cliffs: Prentice-Hall, 1970), p. 171.

${ }^{4}$ David W. Ziegler, War, Peace, and International Politics, 2nd ed. (Boston: Little, Brown and Company, 1981), p. 10 .

5 ziegler, p. 19-20.

${ }^{6}$ Bruce Russett and Harvey Starr, world Politics (San Francisco: W. H. Freeman and Co., 1981), p. 171. ${ }^{7}$ See for example, E.H. Carr, "Military Power," in The Theory and Practice of International Relations or for a general discussion see, Renneth w. Thompson, ed., Moral Dimensions of American Foreign Policy (New Brunswick: Transaction Books, 1984).

${ }^{8}$ Gordon A. Craig and Alexander L. George, Force and Statecraft (New York: Oxford University Press, 1983), p. 273 . 
9 As quoted by Craig and George, 273.

${ }^{10}$ Arnold Wolfers, "Statesmanship and Moral Choice," in Contemporary Theory in International Relations, ed. Stanley Hoffman (Englewood Cliffs: Prentice-Hall, $1960)$, p. 275 .

${ }^{11}$ Ibid, p. 275 .

12 Hans Morgenthau, "Politics Among Nations," in Contemporary Theory in International Relations, ed. Stanley Hoffman (Englewood Cliffs: Prentice-Hall, $1960)$, p. 61 .

13 Ibid.

${ }^{14}$ E.H. Carr, "The Twenty Years' Crisis,"

in Contemporary Theory in International Relations, ed. Stanley Hoffman (Englewood Cliffs: Prentice-Hall, $1960)$, p. 264 .

${ }^{15}$ Craig and George, 271.

${ }^{16}$ Ibid.

17 ziegler, p. 7.

${ }^{18}$ Robert Mandel, "The Effectiveness of Gunboat Diplomacy," International Studies Quarterly 30 (1986): 59 .

${ }^{19}$ Daniel Frei, ed., Managing International Crisis

(Beverly Hills: Sage Publications, 1982), p. 13.

20 Morgenthau, "Politics Among Nations," p. 59.

21 oran R. Young, The Politics of Force (Princeton: Princeton University Press, 1968), p. 310. 
${ }^{22}$ Thomas C. Schelling, Arms and Influence (New Haven: Yale University Press, 1966), p. 35.

${ }^{23}$ Raymond Aron, "The Evolution of Modern Strategic Thought," in Problems of Modern Strategy (New York: Praeger for the Institute for Strategic Studies, 1970), p. 15 .

24 Michael Howard, "The Classical Strategists," in Problems of Modern Strategy (New York: Praeger for the Institute for Strategic Studies, 1970), p. 47.

25 Bernholz, p. 15 .

${ }^{26}$ Howard, p. 47.

${ }^{27}$ See Craig and George, Force and Statecraft.

${ }^{28}$ See for example, Alexander L. George, David $\mathrm{K}$. Hall, and william E. Simons, The Limits of Coercive Diplomacy (Boston: Little, Brown and Co., 1971).

${ }^{29}$ Thomas C. Schelling, "The Diplomacy of Violence," in The Use of Force, eds. Robert J. Art and Kenneth N. Waltz (Boston: Little, Brown and Co., 1971), p. 98. ${ }^{30}$ The following information is based on an article by Duncan Snidal, "The Limits of Hegemonic Stability Theory," International Organization 39 (1985): 579-614.

${ }^{31}$ Gary L. Scott and Craig L. Carr, "Are States Moral Agents?" Social Theory and Practice 12 (1986): 95.

$$
\begin{array}{ll}
32 & \text { Ibid. , } 96 . \\
33 \text { Ibid. , } & 75 . \\
{ }^{34} \text { Ibid., } 90
\end{array}
$$


${ }^{35}$ Ibid., 96.

${ }^{36}$ Ibid.

37 Ibid., 94.

38 Ibid.

${ }^{39}$ Ibid.

40 Frei, 190. 
CHAPTER II

\author{
EXAMINATION OF U. S. FOREIGN POLICIES \\ AND THE USE OF FORCE IN THE CARIBBEAN BASIN
}

The term Caribbean Basin refers to the Central American Isthmus and Maritime Caribbean nations. ${ }^{1}$ Therefore, this area is:

Bounded by the Bahamas in the north and Barbados to the east, the Caribbean is one vast natural chain commanding the Atlantic-Pacific and northsouth trade routes. Guyana and Belize are already traditionally viewed as Caribbean states but so, too, are Guatemala, Honduras, El Salvador, Nicaragua, Costa Rica, Panama, Columbia, Venezuela, Suriname, Mexico and French Guiana.

\title{
EARLY SOURCES OF THE REGION'S PROBLEMS
}

In order to analyze and recalculate U.S. policies in the Caribbean Basin, it is necessary to have an effective understanding of the region itself. It is clear from numerous historical examples that the United States has intervened often in the Caribbean Basin. Yet, U.S. policies of force have not seemed to significantly alter the problems of the region, and these military strategies have required repeated employment by the United States. Furthermore, responding to each isolated occurance has not been very helpful: "Something systemic is going on and, until the 
syndrome is diagnosed, treating each isolated recurrence will get us nowhere." 3

Part of the difficulty in correctly assessing the region's problems stems from the individual features of each nation. A variety of relationships between the elite, the government, and the peasants exists due to differing historical, geographic, or social conditions. 4 For example, the societies of various countries reflect the cultures of the colonizing counries--the English in Belize, the French in Haiti, or the Spanish and U.S. influence in Puerto Rico. Yet most analysts would agree that there are common historical roots to the region's problems. Colonialism is a factor that the Caribbean nations had in common. In general, the native populations were displaced from their lands by the colonizers. Plantations developed with coffee, bananas, and sugar predominating as the major export crops. It has been argued that the coffee production developed a more dominant oligarchy which relied more strongly upon the military to prevent reforms (such as land redistribution) and a consequent loss of the colonizer's power. 5 However, the sugar, banana, and other business owners also resisted reforms and maintained extensive control over all aspects of the Caribbean countries $^{6}$ It has been agreed generally that these large companies and owners operated in their own interest, making "only a limited contribution" to a country's development. 7 During this period of time, the Caribbean 
Basin area was subordinated to European interests. The well-being of the region's economy relied upon exports and was therefore vulnerable to outside forces. The native populations suffered, and declined in members. For example, it has been estimated that after fifty years of conquest, the Indian population of El Salvador declined from as many as 500,000 to about $75,000 .^{8}$ African slaves were brought into many areas with the consequence that colonialism even altered the ethnic structure of the societies. It has been estimated that from 1450-1888, some ten million Africans were captured and transported to the Caribbean area. ${ }^{9}$

The inequitable conditions created by colonialism have contributed to the present-day political instability of the Caribbean Basin. ${ }^{10}$ The exploration, conquest, colonization, slavery, the export economy, the racial and ethnic admixture have all contributed to the problems of the present day--including poverty, unemployment, underdevelopment, economic dependency, social rivalries, ethnic animosities, weak identity, and political disunity. ${ }^{11}$

\section{U. S. RESPONSES TO THE REGION'S PROBLEMS}

Instability and weakness in the Caribbean Basin has led to intervention in its affairs by many countries, including the United States. While the United States has suggested or helped to implement reform measures, or has extended economic aid, over time the United States has also employed a variety 
of military strategies in the Caribbean Basin. U.S. military influence attempts have included shows of force, especially naval ones. Threats, both implicit and explicit, also have been made to Caribbean Basin states. When threats or other military signals have failed to alter the behavior of states in a desired fashion, the United States often has resorted to invasion. Other military strategies have also been employed. For example, coercive diplomacy was employed in both the Cuban Missile crisis and the use of covert activities in Nicaragua. While the United States has worked with international or regional organizations, it is clear from these historical examples that the United States will resort ultimately to military strategies if this seems the best way to achieve its objectives.

\section{Ad Hoc Responses}

In spite of its close proximity to the Caribbean Basin, the United States has often been preoccupied with other matters with the consequence that policymakers have directed varying degrees of attention to this area. For example, at the time the area of the Caribbean Basin was being colonized by European powers, the United States was involved in establishing its own independence and in expanding its own frontiers. Further settlement, continuing efforts to develop industrialization, as well as internal political matters all consumed much American energy. However, over time, the United States policymakers directed more 
attention to the Caribbean. Yet, U.S. policies have been further complicated by the individual preferences of key policymakers, as with Teddy Roosevelt's emphasis on the "big stick" in contrast to Jimmy Carter's insistence on observing human rights.

\section{U.S. Early Involvement}

Changing Perceptions. Regardless of the lack of a long term formalized policy, U.S. policymakers gradually became more cognizant of the Caribbean Basin (and, in fact, of all Latin America). In the early $1800 \mathrm{~s}$ U.S. attention was drawn to the Caribbean as several Caribbean Basin colonies acquired their independence. For example, Haiti declared its independence in 1804 (and France agreed to this in 1825); and in 1821 Nicaragua, Honduras, and Guatemala each declared their independence. However, newly gained independence did not bring freedom from the interference of other countries.

Even though the United States was involved with its own internal affairs, U.S. policymakers continued to become aware of the importance of the Caribbean Basin. Thomas Jefferson stated, for example, that it was essential to "our tranquility and commerce..." to consider this area under general U.S. influence. ${ }^{12}$ In 1823 the Monroe Doctrine was proclaimed, with the declared purpose to limit European--but not American--interference in the Western hemisphere. 
In spite of the Monroe Doctrine, it has been argued that "the United states did not really become involved in the Caribbean Basin area until after the Spanish-American War."13 This war can be viewed as the event which drew the United States into a series of interventions in the Caribbean and Latin America--thereby drawing the United States into world politics. 14 In support of this argument, it can be noted that U.S. influence increased following 1898. For example, in 1898 Puerto Rico became a U.S. possession; the Spanish were driven out of Cuba, with Cuba created as a U.S. protectorate in 1903, and placed under U.S. military occupation for four years. Also, in 1903, the United States was involved in supporting Panama in its secession from Colombia. In fact, in order to support its preferred policies, the United States had militarily intervened in the Panamanian area thirteen times by 1903.15 Not only had the U.S. embarked upon a course of interventions, but by the early twentieth century, the United states had become "the hegemonic military, political, and economic power in the region. "I6

By 1904, Theodore Roosevelt had announced his corollary to the Monroe Doctrine, that "the United States would be responsible for the conduct of Latin American governments," whether or not they had any ties to any foreign powers. 17 During this period of Roosevelt's "big stick" approach to international relations, U.S. policy came to mean more than 
merely preventing foreign intervention; rather, the idea developed that the United States would have the responsibility to exercise "international police power" to correct "any deficiencies in the internal character of Latin American regimes that might encourage foreign intrusion." 18

At the time of the Corollary, political and economic instability were perceived to be the threats of particular concern. 19 The United States responded to various instabilities in a variety of ways, including threats, interventions, and the drawing up of treaties--often made at gunpoint. 20 For example, in 1906 political instability occurred in Guatemala, leading to a full scale war between Guatemala and El Salvador. This led President Theodore Roosevelt to send the U.S. warship Marblehead to the coast of El Salvador. The extent of U.S. influence is clearly demonstrated by the fact that the cease-fire between El Salvador and Guatemala was signed on board the Marblehead; and when the cease-fire threatened to disintegrate into war in 1907 , the United States again intervened militarily. 21

Dollar and Gunboat Diplomacy. While Theodore Roosevelt's administration emphasized U.S. military action, it has been argued that during the next few years william Howard Taft "replaced bullets with dollars in his policy toward the region." 22 Taft's emphasis on furthering the U.S. economic interests has often caused this period of 
American foreign policy to be referred to as "dollar diplomacy." The United States continued to expand its commercial interests in the Caribbean Basin area. Americans, for example, consolidated sugar interests in Cuba, the Dominican Republic and Puerto Rico.

However, the "use of military force was never, in fact, totally abandoned." 23 while the united States may have tried to avoid using military strategies for political purposes, nevertheless U.S. force was often used to protect American economic interests. 24 As a result of the threat or use of threat, other scholars have referred to such U.S. military strategies as "gunboat diplomacy." 25 Such policies have not been restricted to a particular historical period, but continue to the present.

Security interests. During World War I the United States continued to respond to perceived security problems. For example, after the building of the Panama Canal, Haiti was considered to have considerable strategic value; "the sixty-mile stretch of water between Haiti and Cuba was part of the only direct water link between the eastern coast of the United states and the Panama Canal."26 Political instability occurred in Haiti, but united States marines also invaded Haiti in 1915 "as part of a general plan for the strategic and economic control of the Caribbean region." 27 Once a new government was in place, and U.S. influence seemed assured, then the policy of the U.S. administration primarily 
stressed Haitian strict debt repayments to ensure a positive economic environment for U.S. investors. ${ }^{28}$ In order to facilitate this goal, the U.S. marines assumed management of the customs houses and established martial law. 29 Military bases in other areas also assumed greater importance during the war years, as Guantanamo in Cuba or Chaguaranas in Trinidad. In 1917 "to forestall the possibility of Germany constructing a naval base on the Virgin Island of St. John, the United States purchased the island from Denmark, along with St. Croix, part of St. Martin and St. Thomas." 30 And, in the 1920s, the U.S. government was also concerned about the risk of security in Mexico due to "Bolshevik influences. " 31

Many other examples of U.S. military policies can be cited. For example, U.S. marines invaded Cuba in 1917 and stayed until 1923 "putting down strikes and protecting United States property." 32 The United States also occupied the Dominican Republic from 1916 until 1924, establishing martial law and a U.S. military government. 33 In fact, between 1898 and 1920, U.S. troops landed in the Central American region twenty times. 34

Evaluation of U.S. Early Involvement. As noted, inequitable conditions created by colonialism have contributed to instability and poverty in the Caribbean Basin. The United States has often responded to events or conditions in this area with military strategies. These 
strategies may have seemed to serve the immediate goals of the United States--such as as maintaining political order or providing a favorable economic climate for U.S. investments. However, over a period of time the seemingly successful use of military force caused other problems. For example, in Haiti the United States marines imposed martial law in 1915 to ensure a stable environment. Yet, a growing nationalist movement opposed this action, leading to a demand for the withdrawal of U.S. troops which was agreed to in $1934 .^{35}$ Also, these various military policies contributed to a negative perception regarding the United States. It has been argued that a negative attitude toward the United States is a "permanent factor" in areas of the caribbean; 36 and that past U.S. military policies now mean that "political change in Central America will likely entail no small dose of Anti-Yankee sentiment." 37 This anti-Yankee sentiment has recently been expressed by Daniel oduber, the past president of Costa Rica. In 1985 Oduber wrote that average Central Americans feel as if they are dominated and threatened by "armed thugs;" these thugs are "not the Leninist commissars but the armed sergeants trained by the United States." 38

Therefore, early U.S. responses to the Caribbean Basin proved inadequate. Lasting international order was not achieved; the region's problems persisted; and U.S. military actions created a negative perception toward the United 
States. Unfortunately, the United States still pursued such actions through the next decades.

\section{Temporary Restraints}

After World War I the United States had again emphasized world trade and U.S. investments. The United Fruit company expanded, becoming a powerful force within the Caribbean region. For example, by the 1930s, the United Fruit Company had become the largest landholder, employer, and exporter in Guatemala. 39 In fact, the United Fruit Company became known as "El Pulpo," The Octopus, and emerged as a "formidable foreign political influence in the region." 40 Americans also became involved in oil in Trinidad, bauxite in Jamaica and Guyana, and in manufacturing and tourism in various areas. Many of the Caribbean Basin countries continued to have political instability, and the United States again often responded to problems by choosing military strategies.

However, the stock market crash of 1929 preoccupied Americans, causing a temporary restraining effect on U.S. military policies.

Great Depression. The Great Depression caused worldwide social and political stress, which included the Caribbean Basin. For example, El Salvador had profited from a successful coffee industry, with coffee earnings having produced 95.58 of export profits, funded central and local government, financed internal development (roads, ports, 
railroads), and created employment or even fortunes for many individuals. 41 However, the worldwide depression sent coffee prices downward; thousands of peasants had no work, with even the wealthy suffering. Political repercussions followed. Indian uprisings occurred, and worker's revolts erupted in the cities. In 1930, August In Farabundo MartI returned to El Salvador. In March, 1930, he founded the Salvadoran Communist Party. He, and other leaders, planned an armed revolt. Eventually, the El Salvadoran army executed MartI and as many as 30,000 salvadorans. 42

At other periods the United States may have been more likely to have intervened in El Salvador. However, at a time when the United States was preoccupied with its own problems, the oligarchs within the country had responded to this growing unrest with repression. ${ }^{43}$ still, even though the United States did not actually intervene, it did provide a "show-of-force." During the rebellion, the United States supported the goverment by stationing two destroyers and a naval cruiser carrying Marines off the coast of El Salvador; and the U.S. Marine Air Groups stationed in Nicaragua were also alerted. 44

Good Neighbor Policy. Although the "Good Neighbor Policy" is popularly associated with Franklin Roosevelt (who used the term in his inaugural address), President Hoover had previously initiated the policy. In Argentina Hoover promised to abstain from intervention in the internal affairs of 
the nations south of the border, and he arranged to remove U.S. troops from Haiti and Nicaragua. Hoover even formally repudiatd the Roosevelt Corollary to the Monroe Doctrine. Evaluation of U.S. policies. Analysts have disagreed over U.S. military restraint shown during this period. It has been argued that this shift in U.S. policy was not due to economic or military weakness, but was the result "of moral inhibitions." 45 other analysts have stated that in practice the "Good Neighbor Policy" simply meant the abandonment of international entanglements at a time the United states was "preoccupied with economic matters." 46 For example, the United States had previously intervened in Nicaragua to ensure the second term of Adolfo Diaz. Rather than interpreting the withdrawal of the marines as a moralistic action, it can be argued also that when the U.S. marines proved unable to capture Sandino, they were withdrawn (January $1933) .47$

Even if the United States may have been somewhat restrained by moral inhibitions or practical considerations during the time of the "Good Neighbor Policy," the United States presence remained dominant in the Caribbean Basin and the United States still resorted to military strategies. "Shows-of-force" were still designed to influence the behavior of other countries--as in Cuba, in the 1930s, when 30 warships were stationed around the island to protect American interests. 48 
World War II and Strategic Imeratives

With the U.S. involvement in World War II the United States once again had less time for intervention in the Caribbean Basin countries. However, the United States recognized the strategic importance of the area. During the war years, the U.S. military presence in the Caribbean increased. Expanded military installations were constructed in Panama, Puerto Rico, and the Virgin Islands; bases were also set up in Trinidad, Barbados, St. Lucia, and British Guiana.

Panama Canal and Defense Treaties. The Panama Canal was regarded as particularly strategic. In 1936 the United States had signed a General Treaty of Friendship and Cooperation, 49 and had relinquished the right to unilateral intervention in Panama's political affairs. However, that treaty did allow the United States to obtain access to additional lands and waters relating to the defense and modernization of the canal. And in 1942, the U.S. Panama Base Convention 50 was signed, allowing the United States over 100 new military and telecommunications facilities in Panama.

As well as increasing attention to the Panama Canal Zone, the United States took other steps to increase its security. In 1947 the United States and the nations of Latin America completed the Rio Treaty. 51 security was 
emphasized by the phrase in which the parties agreed that "an armed attack by any state against an American state shall be considered as an attack against all the American States," and consequently, each one of the states agreed to aiding the attacked state. $^{52}$ The Rio treaty was soon followed by the creation of the Organization of American States 53 in Bogota, Colombia, in 1948. While the OAS provided for state security, it also established guidelines for hemispheric conduct whch ruled out intervention by one state in the affairs of another.

Evaluation of U.S. Policies. It has been argued that it is the duty of a state to manage international uncertainty in the best interests of its citizens. While it may have been the intent of the U.S. policymakers to achieve this goal, U.S. strategies have not accomplished this. Previous U.S. military interferences in Panama had negative effects upon the U.S.-Panamanian relationship even during the time of war. For example, Arnulfo Arias was elected as President of Panama in 1940 on a platform which emphasized strong "anti-Yankee nationalism." 54 Although he was overthrown the next year--when he resisted U.S. pressure for more military bases during World War II--his ideas and anti-Yankee sentiment remained popular. Be was so popular, in fact, that he was reelected in 1949 (although again removed by a coup in 1951). Furthermore, during the world War II period, Panamanian nationalism erupted in repeated riots in reaction 
to the United States demands for more bases to defend the Canal. 55 And, finally, in 1947, mass protests prevented an agreement to increase the U.S. military presence in Panama. 56

The past--and continuing--U.S. military presence in Panama still negatively affects the U.S.-Panamanian relationship. The United States initial involvement in the establishment of the Panamanian state and its subsequent military (as well as economic and political) influence in Panama has resulted in Panama's resentment toward the United States. Many examples can be cited to indicate the resentment. For example, in 1964 anger against U.S. authorities (who had restrained Panamanian students from positioning their national flag beside a U.S. flag at a high school in the Canal Zone) resulted in 30,000 Panamanians demonstrating in the streets of Panama City. By the time the riots ended, the physical damage exceeded $\$ 2$ million; 28 deaths had occurred, and 300 more were wounded. Panama's resentment toward the United States in regard to the ownership and operation of the Canal itself has abated somewhat. In 1977 the United States and Panama finally reached an agreement regarding the Canal, with the United States retaining the right "to manage and operate the canal until the year 2000," and with the United States having "perpetual authority" to use its military "to protect and defend the canal"--as well 
as having "the perpetual right to build a new sea-level canal ten miles to the west. 57

Yet, there is resentment concerning some of the terms of the treaty ${ }^{58}$ and concerning the continuing U.S. presence in the area. For example, the United States continues to control the School of Americas military training center. It is possible that such issues "related to the continuing U.S. military presence could mobilize national resentment again. " 59

The Panama Canal and the treaty systems established in the 1940s have continued to be important to the United States; and the Caribbean Basin countries no doubt hoped the OAS Charter would involve a new relationship with the United States. The OAS Charter could be viewed as a step toward less military intervention by the United States:
For the first time it seemed to free them (the Latins) from the fear of the big stick which had been applied against them so of ten in the past. For the United States, as well, it was a radical break with the past, a final and explicit repudiation of 'gunboat diplomacy' and a recognition that the Monroe Doctrine could no longer be used as an excuse for unilateral interventions designed to punish or intimidate recalcitrant states.

However, the treaty systems did not lead to less military interference from the United States. As the Soviet Union and communism became an ever-increasing worry, the tension between the Soviet Union and the United States evolved into the cold War. And, the heightened tension between the 
superpowers coincided with a new instability among the political governments of the Caribbean Basin area.

\section{Cold War Influences}

During the cold war period, U.S. policies particularly emphasized the necessity of maintaining control over the Caribbean Basin; it was considered essential for U.S. Welfare to exclude the left from power. In fact, keeping the left from power was defined "as furthering U.S. national interest" 61 and viewed as preventing potential military threats. During this time it was a consistent policy assumption that the United States must prevent leftist movements from becoming leftist governments, for communist success in one country would provide a platform for the revolution to spread to the next country (domino theory). 62 If U.S. diplomatic efforts or development efforts failed to provide the necessary stability in the Caribbean Basin, then the United States relied upon military force, as can be demonstrated by events in Guatemala, Cuba, and the Dominican Republic.

Guatemala. Guatemala in the 1950 s represented an area which was affected by Cold War perceptions. Reforms had been attempted by the government of Jacobo Arbenz which could be interpreted as long needed restitution of economic inequalities or which could be viewed as extreme socialistic/Marxist programs that threatened democracy in Guatemala. It can be argued that the promise of Arbenz to reform the economy of 
the country was not totally revolutionary; yet such reform effort "inevitably meant" confronting the large U.S. corporations in Guatemala, notably United Fruit, International Railways of Central America, and Electric Bond and Share Company. 63 In 1953 and early 1954 the government began a land reform program, expropriating over a thousand estates and distributing this land to over 100,000 families. ${ }^{64}$ The Guatemalan government also expropriated 387,000 acres of land from the United Fruit Company. ${ }^{65}$ These reforms seemed extreme to many. When Arbenz then legalized the Communist Party the new government seemed even more radical. Communist involvement in the Arbenz government was in actuality limited to a "small number of Communists" in "low-level cabinet positions." 66 Further, the Arbenz government can be viewed as "an elected government" which was attempting to carry out "a program of indiginous economic and political liberalizations." 67 However, the reform actions of Guatemala were viewed from a cold War perspective: "The United States government had determined that communism should not gain a foothold in this hemisphere." 68 In 1954, the U.S. government stated it feared the growth of communist power in Guatemala, and the United States pressured several reluctant delegations to secure passage of a key resolution at the Tenth Inter-American Conference (held at Caracas, 1954).69 The resolution declared that the domination or control of the political institutions of any American state by the 
international communist movement would endanger the peace and security of the hemisphere, and would necessitate a meeting of consultation to recommmend appropriate measures. Such a meeting was proposed soon after the resolution was approved, but before the meeting could be assembled the Guatemalan government was overthrown by U.S.-supported forces. 70

Once again, the United States had resorted to military strategies. 71 President Eisenhower had authorized a coup in Guatemala. Financial resources were provided to begin covert action against Arbenz. The CIA also supported an exile army in Honduras and Nicaragua and persuaded ex-Colonel Castillo Armas (a right-wing Guatemalan military member) to lead these forces. The CIA then established a small air force in Nicaragua and the Panama Canal Zone to support Armas's invasion by bombing Guatemalan cities. These planes were piloted by U.S. Navy airmen who reportedly served as mercenaries. The communist threat seemed removed; Arbenz was forced from Guatemala to Mexico; and Armas took power; and all expropriated land was returned to the United Fruit Company •

Events in Guatemala seemed to demonstrate the utility of American military policies. Lloyd Etheredge has argued:

"Eisenhower, and other politicians, learned that covert operations were a useful method for cold war interventions in underdeveloped countries. After the Guatemala success, the role of CIA covert actjivities in American foreign policy expanded. 
In fact, Etheredge has claimed that the policymakers

perception of U.S. strategic success in Guatemala led to the eventual shaping of the plans for the Bay of Pigs invasion. ${ }^{73}$

Cuba. Cuba represented another area which was affected by cold War attitudes. In Cuba, once again seeking to achieve political stability, the United States had supported Fulgencio Batista. The United States operated on the assumption that a strong government, backed by the military, was the most capable of preventing the emergence of a communist government. ${ }^{74}$ However, the Cuban revolution occurred in 1959, with Fidel Castro, a self-proclaimed Marxist, succeeding to power. Cuba turned increasingly to the Soviet Union for assistance.

President Eisenhower responded to this situation by endorsing the supplying of arms to counter-revolutionaries within Cuba. At this time, "the CIA was working closely with Cuban exiles in Florida who carried out acts of sabotage and even bomb attacks on Cuba from the air." 75 As castro continued to further his relationship with the Soviet Union, Eisenhower endorsed a CIA recommendation" to begin to train and arm Cuban exiles for an invasion," with Guatemala being used as a base for these operations. 76

It was actually in 1961, during the Rennedy Administration, that the Bay of Pigs invasion occurred. An invasion force of 1,400 men was assembled, with the cuban underground and American Air Force planning to assist the 
ex-Batista supporters and mercenaries. 77 Due to the extent of U.S. support for this invasion, this has been referred to as a "CIA surrogate invasion." 78 The Bay of Pigs was unsuccessful and a humiliating experience for U.S. policymakers.

The United States once again confronted the Soviets and the Cubans during the Cuban Missile Crisis of 1962.79 In October, 1962, U.S. policymakers considered a range of policies to deal with the missiles that U-2 photos revealed the Soviets were placing in Cuba. Peaceful options, such as working through the OAS or through negotiators were rejected, being considered either ineffective or so slow-moving that the missiles would be operational by the time discussions and debates were completed. Extreme military actions as conducting an invasion or mounting an air strike were finally eliminated as useful strategies. Choosing these options, for example, would involve killing soviet advisors and technicians as well as Cubans, and would engender a greater risk of mlitary confrontation with the Soviets.

The option finally selected--a naval quarantine--was a military strategy that the United States hoped would be effective. First, the policy was stated by President Rennedy on nationwide television. Kennedy clearly explained (and continued to repeat over the next days) the American position. The Soviet Union was expected to dismantle the missiles (which the United States regarded as offensive rather 
than defensive) and Soviet ships would not be allowed to pass thorugh the naval quarantine if they were carrying missiles or other equipment which would make partially developed missiles operational.

To make the threat of using force seem more believable to Rhruschev, Rennedy backed his words with actions. To emphasize American determination military aircraft were orderd to bases within striking distance of Cuba. Almost 200 naval ships were gathered into a task force, and 200,000 men were placed on alert status. 80

Eventually, the Soviet Union did agree to dismantle the missiles. In return, the United States guaranteed it would not invade Cuba.

Dominican Republic. The United states had previously intervened in this area many times. For example, the United States had occupied the Dominican Republic from 1916 to 1924, with Dominican affairs administered directly by the U.S. military government. 81 In 1930, Rafael Trujillo Molina seized power in a revolt and was elected president later that year. He then ruled as dictator for thirty-one years.

During the Trujillo years the United States had no need to intervene. Trujillo kept tight control over the country, both politically and economically (even controlling an estimated $65-858$ of the country's economic wealth). 82 However, Trujillo was assassinated in 1961. 
After the assassination the next few years were characterized by unrest. Trujillo's assets came under state control following his death, and the new President Juan Bosch resisted pressures to denationalize Trujillo's property. Further, he "sought to limit the power of foreign capital and local landowners while defending the rights of the peasantry. ${ }^{83}$

Evidence exists that the United States, becoming alarmed at the situation in the Dominican Republic, lent support to Bosch's opposition. In October 1963 Bosch was overthrown, and it has been suggested that the leader of the coup was conditionally supported by Rennedy. ${ }^{84}$ Further, the new head of government was Donald Reid Cabral who was reputed to be a local CIA agent. ${ }^{85}$ Bosch was successful in regaining his power in a coup in April 1965, but this led to the CIA immediately attempting to set up an alternative junta under Colonel Benoit. Hearings before the Senate Foreign Relations Committee later in the year revealed that on April 28 there was:

...a cabled request from Benoit to Us Ambassador Bennett for American troops 'because a Communist takeover threatens'. But U.S. intelligence reports had stated that same day that no more than two of the 'prime leaders of the rebel forces (were men) with a long history of Communist association.' Ambassador Bennett then informed Benoit that American troops could only be brought in if the justification became the need to protect American lives. Benoit's second cable read: 'Regarding my earlier request, I wish 8 to add
that American lives are in danger... 
It would appear that Benoit's cable provided the justification for a direct U.S. policy of using force. That same day the United States ordered 400 marines from bases in the Caribbean to the Dominican Republic; later, a further 20,000 U.S. marines were sent by President Johnson to deal with the communist threat.

On May 2, 1965 the president proclaimed what soon became known as the Johnson Doctrine:

Revolution in any country is a matter for that country to deal with. It becomes a matter for hemispheric action only when the object is 8 the establishment of a Communist dictatorship.

In a nationwide broadcast, President Johnson emphasized the need for hemispheric security by stating: "The American nations cannot, must not, and will not permit the establishment of another communist government in the Western Hemis phere. " 88

The U.S. invasion had immediate results. Juan Bosch, who had been democratically elected in 1963, was prevented from returning to power. A year after the U.S. invasion, an election was held between Juan Bosch and Joazuin Baluger, who was supported by the United States. After Baluger was elected, the remaining U.S. troops were withdrawn.

Evaluation of U.S. Policies. As has been documented, during this early cold war period the United States demonstrated that it would use military strategies when they seemed useful. In one respect, the policies employed by the United States in the Caribbean Basin seemed successful. 
Reform movements that might have furthered communism were halted in Guatemala and the Dominican Republic while Cuban and Soviet military influence was limited by the Soviet agreement to withdraw its missiles from Cuba. Still, aspects of U.S. actions suggested problems with these policies. In Guatemala a U.S. approved order was restored, but unrest has remained. As previously noted, poverty and inequality are the real sources of instability; therefore, imposed order that does not address these problems is only temporary. ${ }^{89}$ There is a clear need for reform in Guatemala. For instance, "in Guatemala the top two percent of the population receives 25 percent of the income, while the bottom 50 percent receives from 10 to 15 percent. " 90 Yet those who would advocate change have been labeled as "communists" by the military and oligarchy.91 In fact, "since the fall of Arbenz, elections and reformist parties have meant little in terms of fundamental change." 92 Unfortunately, the United States has aided in the suppression of reform by its support of the military and oligarchy. 93 Furthermore, the U.S. interference and sponsorship of political violence has severely damaged the Guatemalan political system itself. 94 Testimony before the Senate Foreign Relations Committee in 1967 indicated that the U.S.-aided alliance between the military and oligarchy did nlittle to improve military respect for civilian authority and constitutional processes. 95 
It would appear that the fear of communism in Guatemala may have limited certain political choices. It has been suggested that pursuing a course of "strategic consequentialism" is the most effective way of managing international uncertainty and that policy options must be constantly recalculated in order to achieve the most effective U.S. action. Yet, events in Guatemala suggest that "once Arbenz had been perceived as a communist the die was cast" and he must be stopped. 96 Such a response to communism and reforms may prevent other useful options from being selected. In 1967 Senator Fulbright suggested that American foreign policy needed to be more effective and realistic:

American interests are better served by supporting nationalism than by opposing communism, and when the two are encountered in close association it it in our interest to accept a communist government, rather than to undertake the cruel and all but impossible tas ${ }_{7}$ of suppressing a genuinely national movement.

In dealing with Cuban problems, U.S. policies regarding the Bay of Pigs invasion seem clearly non-utilitarian; strategies during the Cuban Missile Crisis can be interpreted as more useful.

The CIA sponsored covert activities and the Bay of Pigs invasion were not successful. For example, the underground networks supported by the CIA and disaffected Cubans "were almost always" infiltrated by Castro supporters; supplies of munitions sent to Cuba were "frequently intercepted;" clandestine cells were "not well organized;" and teams sent 
to Cuba to infiltrate Cuban groups were "picked up" within a short time. 98 Further, the American-supported bombing raids in Cuba have been characterized as having "no obvious effect" except "to increase the rate of executions" of the suspected anti-Castro Cubans. ${ }^{99}$ In fact, in spite of covert policies, Castro's regime "not only survived" but his "influence appeared to grow."100 The Bay of Pigs invasion was so unsuccessful that one analyst wrote Rennedy had "been thoroughly defeated by Castro on the beaches in 1961...n101 Numerous problems occurred during the invasion itself. Flaws concerning the military operations included incomplete or inaccurate information regarding the location of reefs or microwave radio stations, the dependence on untested new outboard motors, the utilization of impractical landing craft, and the lack of an effective back-up communication system. 102

Policymakers specifically have been criticized regarding their choice of the entire general strategy. They have been charged with using poor judgment in thinking that previously successful Guatemalan covert policies could be altered and applied to seemingly similar covert actions in Cuba. 103 It has been pointed out that even in Guatemala the U.S. military plan only succeeded by a narrow margin; and in Guatemala U.S.-supported forces only had to contend with a limited military force loyal to Arbenz while the Castro forces numbered over $200,000.104$ Policymakers have also 
been criticized for failing to consider fully the possible consequences of an unsuccessful invasion: "Kennedy and his advisers did not consider the implications of a prolonged struggle that might have embroiled the United States had Rennedy not inadvertently scuttled his own operation."105

"The missile crisis deliberations showed that a marked improvement in the policy process could occur."106

In the Cuban Missile Crisis a wide range of options was considered, finally resulting in the choice of a naval blockade. Analysts tend to describe U.S. military policies in this incident as "successful," since the blockade did achieve the objective of limiting soviet power in the Caribbean area at that time, and this was accomplished without resorting to actual warfare. 107

It can be argued that international relations involves a degree of risk-taking and that a state might deliberately choose such a policy to represent the interests of its citizens. However, U.S. policies during the Cuban Missile Crisis did involve high risk-taking as well as the threat of escalation:

If the Cuban blockade had failed, there were few remaining options that president Rennedy could have used without triggering war. Efforts by strategists and civilian leaders to transform force into a highly refined, discriminating instrument that will support an assertive foreign policy and also be appropriate for crisis managment eventually break down if pushed too far. 
The fear of communism also motivated the United States to intervene in the Dominican Republic. Like the 0.S. intervention in Guatemala, this U.S. military action "sent a signal throughout Latin America that the United States was more comfortable with military governments than with democratically elected reformist governments."109 To many states it appeared the United States would be prepared to intervene with military force if perceived U.S. interests seemed "sufficiently threatened."110 Inter-American treaties--with their accompanying declarations--are quoted by the United States if they can be made applicable to justify U.S. actions; otherwise, these international agreements are simply disregarded. 111

As a result of perceived U.S. successes in these confrontations and the continuing fear of communism, U.S. policymakers continued to rely upon military strategies in the Caribbean area. 112 For example, in the 1960 s the Canal Zone became a center for training in counter-insurgency techniques, and "by 1971 military investment in the Canal Zone was estimated to be \$U.S. 4,800 million."113 And, when guerilla groups appeared in Guatemala and Nicaragua in the early 1960s, the United States responded with "Operation Brotherhood," a series of naval exercises, designed to discourage any more political instability.

In 1964 the United States encouraged the establishment of the Central American Defense Council (CONDECA). Although 
the United States still maintained a military presence in the region, the establishment of CONDECA indicated the American preference for employing national and neighboring armed forces to protect U.S. interests rather than sending in American soldiers. 114 The United states experience in vietnam would reinforce this preference.

\section{Vietnam Influence}

During the latter years of the Johnson administration, Vietnam consumed official Washington's attention. During the Nixon administration the Vietnam experience influenced the American decision-makers' perspectives regarding international relations, including views of the Caribbean Basin. In particular, American policies continued to stress military security, rather than economic development and reform in the Caribbean Basin area. 115

There were several developments in the Caribbean that seemed disturbing to U.S. decision-makers. The "domino theory" was subscribed to by many; just as the United States had to worry about the "domino theory" in Southeast Asia, many U.S. State Department spokesmen worried about countries in the Caribbean becoming communist and therefore creating a "sea of splashing dominoes" in that area. 116 During the 1960s and 1970s many countries in the Caribbean Basin had become independent (in the 1960s--Jamaica, Trinidad, Tobago, Guyana and Barbados, and in the 1970s--Bahamas, Grenada, 
Dominica, St. Lucia, St. Vincent, and Suriname). However, as in other historical periods, independence did not bring about social or political transformation of these areas. Political and social inequalities continued to exist. Further, Cuba demonstrated an interest in promoting socialist policies and governments in the Caribbean, a fact which concerned the United States. 117 For example, Guyana's government had moved toward socialism; in 1973, Castro visited Georgetown, and Guyana appeared to have a very radical government. Jamaica also seemed to be leaning toward radicalism. Michael Manley had come to office in 1972 and Jamaica proceded to embark upon socialistic reforms. In Grenada, in March 1979, an insurrection was launched and the government of Eric Gairy was replaced by a government under Maurice Bishop which proceded to forge links with the Cubans and Soviets. Other new governments established during the 1970s, as St. Lucia and st. Vincent, also stressed reform and socialistic measures. Since these new governments appeared within months of the Grenadian revolution of 1979 it might have seemed as if the Cuban experience would promote communism in other areas.

Puerto Rico and the Virgin Islands also claimed U.S. attention during this time. Puerto Rico had been a self-governing "Commonwealth" since 1950, associated with the United States. However, by 1975, Puerto Rico had serious 
problems. For example, "seventy per cent of the population was sufficiently impoverished to be eligible for U.S. food coupons."118 Theoretically Puerto Rico had internal political independence, but questions regarding the colonial nature of the relationship of Puerto Rico to the United states were being raised in the international community. For example, in 1972 Cuba brought the Puerto Rican issue to the U.N. Committee on Decolonization. "The United States denied that Puerto Rico was a colony and maintained that the issue was an 'internal' one of no concern to the international community."119 Yet, in 1978 , a U.N. resolution by the Decolonization Committee stressed that "only through a complete transfer of power from the United States to the people of Puerto Rico could the latter be able to decide freely its political future," and the committee asked the United states to present a plan providing for the future political independence of the island. 120 However, the United States government has stressed support for statehood rather than for independence. ${ }^{121}$ In the case of the virgin Islands, they were bought by the United States from Denmark in 1917, and these islands have a similar relationship to the United States with the exception that there is less internal autonomy than in Puerto Rico. Although these areas have been of concern to the United States (especially with recent terrorist activities), the United States has chosen to rely on policies other than military ones. 122 
The U.S. experiences in Vietnam emphasized the problems of relying upon military strategies. Various analysts began to challenge the past U.S. policies of military force in the Caribbean Basin. For example, zbigniew Brzezinski argued that the United States should review its priorities, particularly the hard stand on anti-communism and hemispheric security. 123 In 1974, the Commission on United StatesLatin American Relations which was headed by Sol Linowitz, recommended that the United States abandon military intervention as a weapon of hegemonic assertion. Specifically, Linowitz argued that the United States should "keep local and regional conflicts outside the context of the super power relationship," and should not regard all conflict as battlegrounds of the cold war. 124 The Commission did, however, retain the traditional view that "Cuba was a special problem" to the United States, requiring U.S. policies aimed at restraining Cuba. 125

\section{Alternatives to Force in the Caribbean Basin}

The United States has not only relied upon military strategies in the Caribbean Basin; rather, U.S. policies reflect a mixture of ad hoc responses to perceived problems. 126 At various times U.S. policies have stressed being a "Good Neighbor" as well as the threats of coercive diplomacy or the actual force of intervention.

The "Good Neighbor" policy and general attempts to promote reform have already been discussed. However, during 
the 1960s and 1970s two alternative attempts to U.S. military strategies are particularly noteworthy--the Alliance for Progress and the emphasis on human rights as developed by Carter.

Alliance for Progress. Recognizing the problems of inequality and the need for reform, President Rennedy announced the Alliance for Progress. The United States pledged twenty billion dollars in aid for Latin America. Government officials announced that the United States hoped to help eliminate the problems that caused nations of the Caribbean area to turn toward communism. And, the Alliance for Progress did give impetus to reform groups--popular associations and new political parties that sought the kinds of revisions that the Alliance had promoted. 127 However, the Alliance failed to produce "the enduring political and economic reforms" that had been proposed. This was partly due to the fact that U.S. policymakers seriously underestimated the entrenched power and the tenacious resilience of the traditional upper classes to resist sharing their privileges. 128

Although government officials emphasized the Alliance for progress as an alternative to military strategies, "the Alliance also included a military security component designed to defeat any revolutionary challenge that might preempt or disrupt attempts at reform."129 For example, the school of the Americas was utilized as a military training center for 
counterinsurgency measures. 130 Also, the U.S. Agency for International Development (AID) was established; regional police forces were provided with training and supplies-including general arms, antiriot guns, communications and transportation equipment. 131

Emphasis on Human Rights. Questions regarding the appropriateness and effectiveness of military strategies regarding foreign policy were raised toward the end of the Kissinger-Ford era, but especially during the carter Administration. ${ }^{132}$ The Carter administration directed more attention, skilled officials, and aid to the Caribbean than previous adminstrations had; and developed the concept that the United States should be willing to tolerate a degree of ideological pluralism in the region. ${ }^{133}$ The idea was advanced that it was to the U.S. advantage to avoid military strategies, stressing instead human rights. "Although applied with some inconsistency, the advocacy of human rights regained for the United States some of the respect among centrist and democratic forces which had been lost in the wake of its vietnam and Chile experiences." 134 The U.S. emphasis on human rights (in spite of inconsistent policies) promoted the development of a political center in the Caribbean area while encouraging needed reforms. ${ }^{135}$ For a time it seemed these new policies promised the inauguration of an era of friendly cooperative relations between states. 136 However, during Carter's term in office there 
was a change in foreign policy. Liberal policies were replaced by more conservative ones.

Several international events reinforced the worries of American decision-makers. The Soviets had invaded Afghanistan. Iran had captured the American embassy, taking American hostages. And, in 1978, Cuba had sent troops to Ethiopia which not only brought an end to the slow process of normalization that had been developing in the United States-Cuban relations, but reinforced U.S. anxieties about Soviet-Cuban military intentions in the Third World. 137 The United States worried also about the presence of "MIG 23 attack aircraft which could conceivably carry nuclear weapons" and about the presence of soviet combat brigades in Cuba. 138 Despite Soviet and Cuban reassurances, a further decline in United States-Cuban relations occurred.139 Then, in 1979 the Nicaraguan revolution added further concerns for American foreign policy.

The view came to be stressed that "Communism was the principal danger facing the world" and that "its spread should be resisted." 140 Further, Cuba was regarded as a surrogate of Moscow, responding to Soviet directions. The United States primarily relied on military measures to deal with the perceived problem of Communist influence in the Caribbean. A view developed that Carter's earlier approach had focused too much upon constraints and limits regarding 
American actions; instead, "there ought to be greater efforts to project American power abroad in order to achieve a tighter grip on global political developments."141 In fact, Communism ought to be resisted by the United states "with all means at its disposal."142 The renewed emphasis on military strategy included the decision to set up a new Caribbean Joint Task Force Headquarters in Rey West, Florida, and to expand the U.S. naval maneuvers in the Caribbean. 143 American warships were seen more frequently in the area, participating in shows of force like "operation solid shield $80 ; "$ this exercise occurred in May 1980, involving more than 20,000 men and 42 naval vessels. 144

\section{Conservative Comeback}

When President Reagan took office in 1981 he brought with him "a deeply ingrained cold war perspective of inter-American relations. "145 This is particularly evident in his view of Nicaragua. Carter policy had initially seemed to pursue policies aimed at cooperation rather than confrontation. 146 However, the Reagan Administration would bring an end to this approach. The sandinista movement in Nicaragua was regarded as a Cuban inspired revolution. In fact, with the Sandinista success Nicaragua was regarded by many in the Administration as "lost;" El Salvador and Guatemala were viewed as "endangered;" Mexico was "threatened;" and ultimately the United States--as "the last domino"--would also be endangered. ${ }^{147}$ This concern for 
security from cuban inspired revolutions affected the perceptions of the United States regarding the caribbean Basin area. It is, in fact, significant that the Reagan Administraiton "drew no distinction between the Caribbean and Central America," but referred to the area by a newer concept, the Caribbean Basin. 148 Some analysts have argued the small areas of this region really have little in common beyond their close proximity to the United States "but were forced together by the administration's determination to reassert U.S. hegemony in the area and expunge Cuban influence for good." 149

As a result of its concern over Cuban initiatives the United states developed several poliicies to restrain Cuban influence, including anti-Cuban broadcasts, and economic and diplomatic efforts to reward or punish caribbean states which seemed too socialist or reformist; but the United states continued to rely on military policies also. 


\section{ENDNOTES}

${ }^{1}$ Carlos deMeira Mattos et al. "Security in the Western Hemiphere," Atlantic Community Quarterly 22 (1985): 361 .

${ }^{2}$ Richard Sims and James Anderson, "The Caribbean Strategic Vacuum," Conflict Studies, no. 121 (London: Institute for the study of conflict, 1980), p. 2.

3 Eldon Kenworthy, "Central America: Beyond the Credibility Trap," in The Central American Crisis, ed. Renneth M. Coleman and George C. Herring (Willmington: Scholarly Resources, 1985), p. 111.

${ }^{4}$ peter H. Smith, "The Origins of Crisis," in Confronting Revolution, eds. Morris J. Blachman, William M. LeoGrande, and Kenneth E. Sharpe (New York: Pantheon, $1986)$, p. 7 .

5 Ibid, p. 6. ${ }^{6}$ Ibid, p. 8 . 7 Ibid.

${ }^{8}$ Tom Barry and Deb Preusch, The Central America Fact Book (New York: Grove Press, 1986), pp. 198-199. ${ }^{9}$ Gordon $\mathrm{R}$. Lewis, Main Currents in Caribbean Thought (Baltimore: John Hopkins University Press, 1983), p. 5 . 
${ }^{10}$ Richard McCall, "From Monroe to Reagan: An Overview of U.S.-Latin American Relations," in From Gunboats to Diplomacy, ed. Ricard Newfarmer (Baltimore: The Johns Hopkins University Press, 1984), pp. 15-16.

${ }^{11}$ Lewis, p. 7 .

${ }^{12}$ Morris J. Blachman, et al., "The Failure of the Hegelmonic Strategic Vision," in Confronting Revolution, eds. Morris J. Blachman, William M. LeoGrande, and Kenneth E. Sharpe (New York: Pantheon, 1986), p. 330.

${ }^{13}$ Mccall, p. 20.

${ }^{14}$ Ibid.

${ }^{15}$ Ibid.

${ }^{16}$ Blachman, p. 330 .

17 McCall, p. 21 .

${ }^{18}$ Blachman, p. 330 .

19 Ibid, p. 331 .

20 Jenny Pearce, Under the Eagle: U.S. Intervention

in Central America and the Caribbean. Boston: South End Press, 1982 .

${ }^{21}$ Simon Collier, Howard Blakemore, and Thomas E. Skidmore, eds. The Cambridge Encyclopedia of Latin America and the Caribbean (Cambridge: Cambridge University Press, $1985)$, p. 229 .

22 pearce, 12 .

23 Ibid, p. 17.

$24 \mathrm{McCa} 1$, p. 22. 
25 Ibid.

26 Pearce, p. 19.

27 Collier, p. 282 .

28 Ibid.

29 Pearce, p. 19.

${ }^{30}$ Collier, p. 292.

${ }^{31}$ Richard Millet, "Praetorians or Patriots? The

Central American Military," in Central America, ed. Robert S. Leiken (New York: Pergamon Press, 1984), p. 71.

${ }^{32}$ pearce, p. 17.

${ }^{33}$ Ibid.

34 Walter LaFeber, "The Burdens of the Past," in

Central America, ed. Robert S. Leiken (New York: Pergamon Press, 1984 ), p. 49.

${ }^{35}$ Collier, p. 282 .

$36_{\mathrm{McCa}} 1$, p. 22 .

37 Cochrane, p. 777 .

${ }^{38}$ Daniel Oduber, "Is Peace Possible in Central America?" in The Central American Crisis, eds. Kenneth M. Coleman and George C. Herring (wilmington: Scholarly Resources, 1985), p. 196.

${ }^{39}$ Barry and Preuch, p. 226.

${ }^{40}$ Collier, p. 229.

${ }^{41}$ Cynthia Arnson, El Salvador (Washington, D.C.: Institute for Policy Studies, 1982), pp. 12-13. 
42 Barry and Preuch, p. 200.

${ }^{43}$ Phillip Berryman, Inside Central America. (New

York: Pantheon, 1985), p. 13.

44 Barry and Preuch, p. 200.

45 Michael Handel, weak States in the International

System (Totowa, N.J.: Frank Cass, 1981), p. 271.

${ }^{46}$ Pearce, p. 23.

47 Collier, p. 230.

${ }^{48}$ Pearce, p. 23.

49 Barry and Preuch, p. 301

50 Ibid.

${ }^{51}$ Ibid.

52 Barry and Preuch, p. 303.

${ }^{53}$ Ibid.

54 Thomas John Bossert, "Panama," in Confronting

Revolution, ed. Morris J. Blachman, William M. LeoGrande, and Kenneth E. Sharpe (New York: Pantheon, 1986), p. 187.

${ }^{55}$ Ibid.

${ }^{56}$ Barry and Preusch, p. 301.

57 Ibid, pp. 301-302.

58 Bossert, p. 192 .

${ }^{59}$ Ibid, p. 55 .

60 McCall, p. 56 .

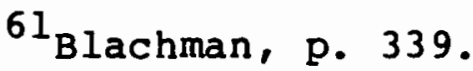

62 Ibid, p. 340 .

63 Barry and Preusch, p. 227. 
64 Berryman, p. 14 .

${ }^{65}$ Barry and Preusch, p. 227.

${ }^{66} \mathrm{McCal1}$, p. 27.

67 LaFeber, p. 52.

${ }^{68}$ Neale C. Ronning, ed. Intervention in Latin

America (New York: Alfred A. Knopf, 1970), p. 18.

${ }^{69}$ Ibid.

${ }^{70}$ Ibid.

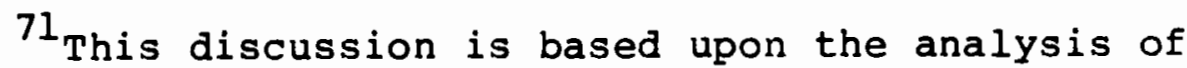
Richard McCall, p. 27.

${ }^{72}$ Lloyd Etheredge, Can Government Learn? (New York: Pergamon Press, 1985), p. 8.

${ }^{73}$ Ibid., p. 1.

74 oduber, p. 196.

${ }^{75}$ pearce, p. 33 .

${ }^{76}$ Ibid.

${ }^{77}$ Ibid.

${ }^{78}$ Thomas . Walker "Nicaraguan-U.S. Friction: The First Four Years, 1979-1983." in The Central American Crisis, ed. Renneth M. Coleman and George C. Herring (Wilmington: Scholarly Resources, 1985), p. 163.

${ }^{79}$ This dicussion involving decision-making in the Cuban Missile Crisis is based on the analysis developed by Graham Allison. See Graham T. Allison, "Conceptual Models and the Cuban Missile Crisis," American Political Science Review 63 (September 1969), 689-718. 
${ }^{80}$ Bruce Russett and Harvey Starr, world Politics (San Francisco: w. H. Freeman and Co., 1981), p. 200. ${ }^{81}$ collier, p. 284 .

82 pearce, p. 62 .

${ }^{83}$ Ibid.

${ }^{84}$ Ibid.

85 Ibid.

${ }^{86}$ Ibid, pp. $62-63$.

$87 \mathrm{McCall}$, p. 29.

88 payne, p. 41.

${ }^{89}$ Robert Trudeau and Lars Schoultz, "Guatemala," in

Confronting Revolution, eds. Morris J. Blachman, William

M. LeoGrande, and Kenneth E. Sharpe (New York: Pantheon, $1986)$, p. 47.

90 Berryman, p. 18 .

91 Trudeau, p. 47.

92 Ibid, p. 48.

93 Ibid, p. 47.

94 Ibid, p. 23.

${ }^{95}$ Pearce, p. 56 .

96 Trudeau, p. 27.

97 Iincoln P. Bloomfield, "Patterns of American

Intervention," in The Theory and Practice of International

Relations, 3 rd ed., eds. Fred A. Sondermann, William C.

Olson, and David S. McLeelan (Englewood Cliffs:

Prentice-Hall, 1970), p. 330 . 
${ }^{98}$ Etheredge, p. 4.

${ }^{99}$ Ibid.

${ }^{100}$ Peter Wyden, Bay of Pigs (New York: Simon and Schuster, 1979), p. 4.

$101_{\text {Wyden, p. } 7 .}$

102 Ibid., pp. 320-323.

103 Ibid., p. 323 .

104 Ibid.

${ }^{105}$ Etheredge, p. 37.

${ }^{106}$ Ibid., p. 86 .

107 McCall, p. 29.

${ }^{108}$ Craig and George, p. 207.

${ }^{109}$ Ibid.

$110_{\text {Ronning, p. } 23 .}$

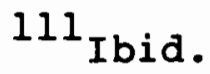

112 Pearce, p. 32.

113 Pearce, p. 57.

114 Pearce, p. 61.

115 LaFeber, p. 51.

${ }^{116}$ Anthony Payne, "Whither CARICOM?" International Journal 40 (1985): 22 .

117 Robert s. Leiken, "Can the Cycle Be Broken?" in Central America, ed. Robert S. Leiken (New York: Pergamon Press, 1984 ), p. 9 .

118 payne, p. 17.

119 Ibid., p. 16 . 
120 Ibid., p. 17.

121 Ibid., p. 18 .

122 Ibid., pp. 4-5.

${ }^{123}$ See for example zbigniew Brzezinski power and

Principle (New York: Farrar, Straus, Girous, 1983).

124 payne, p. 43.

125 Ibid.

126 Ibid.

127 Smith, "The origins of Crisis," p. 12 .

128 Ibid., p. 11 .

129 Ibid., p. 10.

130 Ibid.

${ }^{131}$ Ibid.

132 Payne, p. 43.

133 Ibid., p. 44 .

$134 \mathrm{McCa} 1$, p. 30 .

${ }^{135}$ I bid.

136 Payne, p. 46.

137 Ibid., p. 48 .

138 Ibid., p. 49.

${ }^{139}$ Ibid.

140 Ibid., p. 51.

${ }^{141}$ Ibid.

142 Ibid.

143 Ibid., p. 49 .

144 Ibid., p. 49. 
145 McCall, p. 31.

146 walker, p. 163.

147 payne, p. 53.

${ }^{148}$ Ibid.

${ }^{149}$ Ibid. 
CHAPTER III

GRENADA AND U.S. POLICIES

The Reagan Administration's concerns regarding the spread of communism are demonstrated by the Administration's reactions to events in Grenada. Policymakers in the United States regarded the new developments in the Grenadian political situation as threatening, as providing an area from which growing communist influence could spread to other areas in the Caribbean Basin. The U.S. policymakers responded to this situation by consciously designing options to signal U.S. concern and U.S. determination to halt any further communist developments. Specific military strategies were designed to influence and coerce Grenada into altering its state behavior so that it would be regarded as more acceptable by the United States. When influence strategies failed to alter Grenada's state behavior, the United States resorted to direct intervention.

\section{POLITICAL BACRGROUND}

Grenada, having been discovered by spain and ruled by Britain for two hundred years, became independent in $1974 .^{1}$ Eric M. Gairy served as Prime Minister in a government that 
had American and British support. However, Grenada faced many problems at this time. In 1975 Grenada was one of the poorer countries in the Western Hemisphere, having a per capita income of U.S. $\$ 390$. Further, the economy was not well balanced, being dependent on export products of bananas, cocoa, and spices. Even more problems developed during the Gairy administration. Agriculture for local consumption slumped to the degree that Grenada had to begin importing most of its food, and unemployment increased (estimates range from 208 to a rate of 508 of unemployment). Tourism declined; the balance of payments deficit increased; and political tensions on the island increased.

On March 13, 1979, Gairy's government was overthrown by an almost bloodless coup. The leader of the coup was Maurice Bishop, and his party was called the New Jewel Movement. Shortly after the coup, Bishop declared a socialist democratic and nationalist program of reform. Bishop's program included upgrading education, increasing food production for local consumption, encouraging limited tourism, reform of the bureaucracy, and the building of a new airport. However, Bishop and his new program--with its stress on socialist reform--seemed communist. This communist involvement seemed further evidenced when Bishop invited Cuban military advisors to Grenada. He also increasingly utilized Marxian socialist terms such as "people's militia." 
The new Grenadian government faced opposition from other pro-American governments in the Caribbean. They reacted with hostility to the new government, with the premier of st. Vincent going so far as to ask Britain to send troops to overthrow the new government. ${ }^{2}$

However, even within Grenada there was controversy regarding Bishop. ${ }^{3}$ There were factions--those who favored a broadly social democratic emphasis and those who were committed to Marxism and "the eventual socialist transformation of society." To the latter group, it did not appear that Bishop was moving fast enough toward Marxism-especially since Bishop appealed to both capitalist and socialist countries for aid. At issue also was the increasingly autocratic style of Bishop's leadership.

As a result of political dissension within the New Jewel Movement, Bishop was placed under house arrest on October 13, 1983. Protests grew regarding Bishop's arrest and after a large demonstration on october 19, he was temporarily freed. However, he was later executed on the same day.

In reaction to this act, the United states took strong military action. However, the Reagan Administration's opposition to the revolutionary regime in Grenada had long been evident. 4 


\section{U.S. POLICY RESPONSES}

Viewing the new Bishop government with alarm, U.S. policymakers attempted to communicate U.S. displeasure with Grenada's socialistic measures. For example, the American ambassador Frank Ortiz informed Bishop that the United States would "view with displeasure any tendency on the part of Grenada to develop closer ties with Cuba." 5 As noted, while Bishop did make some accomodating moves toward the United States (such as requesting U.S. aid) the Grenadian government continued along its socialist path.

The U.S. policymakers apparently decided that U.S. intentions needed to be signaled more strongly to Grenada. Naval exercises were chosen as a way of communicating to Grenada that the United States was serious in its opposition to Grenadian policies, and that the United States expected a different kind of state behavior from Grenada.

In August 1981 the United States conducted a large NATO execise in the Caribbean. Analysts have suggested the purpose of the exercise was to "frighten Grenada." 6 This naval exercise was therefore conducted in a "noisy" manner, attracting much publicity--presumably to alter further the state behavior of Nicaragua. ${ }^{7}$ In fact, these exercises could have seemed very frightening to Grenada for they had very suggestive parallels to that country. One of the NATO military exercises included a simulated attack upon the 
island of vieques (located off the coast of Puerto Rico). "The objective was to take power in a fictitious country called 'Amber and the Amberines' (unavoidably suggestive of Grenada and the Grenadines, especially since there was a district called Amber in Grenada) until an election could be called and a pro-U.S. government installed. 8

In order to evaluate the utility of U.S. military strategies, it is necessary to consider whether this military signal was clear to the officials of the Grenadian government. It could be presumed the signals were understandable to the officials in Grenada, as well as to other observors. Some evidence for this viewpoint exists in the fact that debate in the later U.N. General Assembly, debate regarding the eventual U.S. invasion of Grenada, referred to the fact that "the intervention had been planned by the U.S. for a number of years." 9 It could also be argued that these exercises should have been understandable to the Grenadians due to suggestive parallels between Grenada and the mock invasion plans.

However, no matter how carefully devised, communicating intentions by military strategies presents certain problems. For example, even if a nation communicates its intentions correctly, there is no guarantee that a nation's communication will be received correctly. And, regarding the nature of a communicated threat, the threatened action may not have been credible; or Grenada may have just chosen to ignore the 
threat. Furthermore, the assumption that a threat will alter behavior becomes questionable when the decision-makers consider whether they would back down under similar action by an opponent. 10

At any rate, this signaled threat did not have the desired effect upon Grenada, as Grenada continued to develop closer ties to the cubans. And, another U.S. Atlantic fleet maneuver which was conducted in May 1982 also failed to alter Grenadian policies.

Yet, the United States continued to pressure Grenada. In March of 1983, Reagan claimed "the island was housing Cuban and soviet naval bases and other sophisticated military installations," with photographs and comments released which allegedly illustrated military buildup and the military aspects of Grenada's new airport. ${ }^{11}$ During this televised speech Reagan emphasized the strategic nature of the Caribbean Basin:

The Caribbean is a very important passageway for our international commerce and military lines of communication. More than half of all American oil imports now pass through the Caribbean. The rapid build-up of Grenada's military potential is unrelated to any conceivable threat to this island country of under 110,000 people, and totally at odds with the pattern of other eastern Caribbean states, most of which are unarmed. The Soviet-Cuban militarization of Grenada, in short, can only been seen as power projection into the region, and it is in this important economic and strategic area that we are trying to help the governments of El Salvador, Costa Rica, Honduras and others in their struggles for democracy against 12 guerrillas supported through Cuba and Nicaragua. ${ }^{12}$ 
On the same day of Reagan's speech, the United States attempted to physically demonstrate the verbalized concerns. Another naval exercise began in the Caribbean. It was a month long exercise, involving $77 \mathrm{U.S}$. and allied warships. 13

However, the Grenadian government still refused to be intimidated. In fact, Bishop's government in Grenada attacked Reagan's statement, as an "open declaration of war" and placed its military on alert. 14

Reagan continued to make more statements regarding the danger of communism in Grenada. "These statements apparently were intended as warnings to Grenada."15 For example, on April 27th, Reagan addressed a joint session of Congress, and again stressed the importance of Grenada. Specifically, he refered to a recent incident involving Libyan cargo planes. They had been heading for Nicaragua--with a disguised shipment of weapons aboard--and were detained by authorities in Brazil during a refueling stop. Reagan emphasized the strategic location of Grenada by stating: "If that airfield on Grenada had been completed, those planes could have refueled there and completed their journey." 16

There is some indication that these threats and naval maneuvers may have altered the behavior of Grenada at this point. In June 1983 Maurice Bishop decided to visit the 
United States. "In hindsight, Bishop's visit may have been a desperate attempt to head off growing extremist opposition, and he may genuinely have wished to reduce his cuban ties or at least balance them with some links to the United states." 17

However, as previously noted, by October 13, Bishop was arrested by more extremist colleagues. Although he was later freed on October 19, he was executed later on the same day.

At this point the United States responded with the strong military action of actually invading Grenada. Six thousand U.S. troops were sent to the island, accompanied by 300 other soldiers from seven Caribbean states.

The U.S. government employed several justifications for this action. On October 19 several members of the Eastern Caribbean States had met, and six nations requested outside help from the United States. Reagan also justified the invasion as necessary to protect American citizens (especially 800 medical students), as necessary to restore order and democratic rule, and as necessary to eliminate Cuban influence. 18

After the U.S. invasion it is noteworthy that a 1984 election was held in Grenada. Hebert A. Blaize, a member of the centrist coalition became the new prime minister.

EVALUATION OF U.S. STRATEGIES

It is possible to evaluate this military action from a variety of perspectives. In the short term, it can be argued 
that the United States prevented the potential loss of American lives in Grenada or that Cuban-Soviet influence was thwarted. There is evidence to indicate that U.S. actions in Grenada did affect the Cubans. Events in Grenada suggested the Cubans could offer no real military assistance to a socialist government if the United States was willing to use direct military force:

Prior to Grenada there was much speculation as to whether Cuba would follow the precedents of Angola and Ethiopia by sending troops to aid Nicaragua in the event of a conflict between Nicaragua and its neighbors. After Grenada, there was no such speculation. The cubans themselves acknowledged their inability to act militarily in Central America in the face of the pyerwhelming military might of the United States.

In the long run, however, there are aspects of this policy that cause concern. As in earlier cases of intervention, forceful U.S. actions have contributed to a negative perception regarding United States intentions and actions. For example, some speakers debating this issue at the General Assembly of the United Nations referred to the United States as "imperalist" and interested in continuing "colonist domination." 20 The invasion of Grenada was criticized also as being unlawful. The United States argued that it had a right to intervene based on a treaty clause of the Organization of Eastern Caribbean States (OECS), but other countries pointed out that the oEcs document called for a majority of countries to request outside help, not merely the request from six. And, voting in the U.N. General 
Assembly, by a vote of 108 to 9 , the majority of nations approved a statement which "deeply deplored the armed intervention in Grenada as constituting a 'flagrant violation of international law and of the independence, sovereignty and teritory of that state.'" 21 The majority of the membership of the OAS also censured the United States for its actions in Grenada, with the Venezuelan government being particularly outspoken in its criticism. 22 In fact, a number of traditional allies to the United States opposed the invasion, including France, Canada, Mexico, and Britain. 23 The British emphasized the fact that the invasion of Grenada would lessen the West's claim to moral superiority in international relations when comparisons would be made comparing the Soviet invasion of Afghanistan to the U.S. invasion of Grenada. 24 Finally, although ultimately vetoed by the United States, a Security Council resolution deploring U.S. aggression initially received eleven votes to one with two abstentions--this voting can be viewed as "giving some measure of the scale of international opposition to the U.S. action. 25

Another problem with the reliance upon military strategies is that such policies may limit other foreign policy options. It could be argued that the reliance upon military strategies has short-circuited other policies such as negotiation or more flexible, alternative responses--such as a solution which might involve power-sharing between 
capitalistic and socialistic forces within a country. Considering the problems connected with military strategies, the decision that force was necessary needs to be reevaluated. One method of evaluation is to consider what would have happened if no force had been used. Such an analysis is admittedly suggestive and speculative. However, an examination of several other states in the Caribbean suggests that socialist experiments need not lead to full membership in the soviet bloc.

As noted earlier, several states in the $1970 \mathrm{~s}$ developed socialistic policies which alarmed the United States. The United States did not use military strategies to deal with these areas, yet these states have not become threats to the region or to the United States. For example, it was stated that in 1973 Guyana appeared to have a very radical government. However, President Forbes Burnham, who had dominated Guyanese political life since independence in 1966, died in 1985 and was succeeded by Desmond Hoyte who has taken some steps to improve the country's relations with the United States. In Jamaica, it had seemed alarming when Michael Manley had come to office in 1972 and when Jamaica proceded to embark upon socialistic reforms. However, in 1980 Manley lost his reelection bid, and Manley's socialist experiment seems to have been stopped.26 In 1979 Dominica and st. Lucia also acquired new governments which stressed reform and socialistic measures. However, an unusually severe hurricane 
in October of 1979 caused such physical devastation in Dominica that more conservative parties were returned to power to try to cope with the damage. In St. Lucia, the reformist government never really became effective due to "almost incessant feuding." 27 These examples would suggest that an analysis of "splashing socialist dominoes" in the Caribbean has not been accurate.

Further, the use of U.S. force in Grenada can not only be regarded as a specific response to a particular situation, but can also be regarded as a larger U.S. policy position in the Caribbean--a warning of what could happen to other "bad neighbors." 28 It would seem that a group of nations friendly to the United States (good neighbors) could invite the United States to invade a neighbor they see as threatening (a bad neighbor). Such a request could seem quite appealing since the requesting nation would need to contribute only token military forces to the invading force. Instead, direct U.S. force, "either through airpower, seapower, tactical support, or troops," could be sent into the territory of the "bad neighbor." Further, the various regional alliances could provide a ready-made framework for such a request from the Caribbean states.

The Reagan Administration's posture toward Grenada has had clear implications for other nations in the region. In particular, the policy has clear implications for the situation in Nicaragua. The U.S. occupation of Grenada has 
demonstrated the willingness of the United States to resort to pure physical force when other influence methods have not achieved the desired goals of the policymakers. Even though Grenada is a small island one analyst argued the U.S. occupation of Grenada "added bite to the Administration's threatening posture toward Nicaragua." 29 


\section{ENDNOTES}

$I_{\text {The following discussion--from colonization to the }}$ new Bishop government--is based upon Pearce's account in Under the Eagle: U.S. Intervention in Central America and the Caribbean. pp. 121-122.

${ }^{2}$ Pearce, p. 122 .

${ }^{3}$ The discussion regarding the political disagreements that led to Bishop's overthrow is based upon Payne's interpretation in The International crisis in the Caribbean, pp. 161-164.

${ }^{4}$ Payne, p. 163.

5 pearce, p. 123.

6 Payne, p. 55.

7 Mandel, p. 6 .

8 Payne, p. 55.

9"Grenada," U.N. Chronicle 2l (1984): 4-8.

10 Michael P. Sullivan, International Relations: Theories and Evidence (Englewood Cliffs: Prentice Hall, 1976), p. 299.

11 payne, p. 64.

12 Dickey, p. 689.

13 Payne, p. 64 .

${ }^{14}$ Ibid. 
${ }^{15}$ Dickey, p. 689.

${ }^{16}$ Ibid.

17 Ibid., p. 690 .

18 Ibid.

19 William M. LeoGrande et al., "Grappling with

Central America: From Carter to Reagan," in Confronting Revolution, ed. Morris J. Blachman, William M. LeoGrande, and Kennmeth E. Sharpe (New York: Pantheon, 1986), p. 243-4. 20 "Grenada," U.N. Chronicle, p. 4. 21 Ibid.

22 Terry Karl, "Mexico, Venezuela, and the Contadora Initiative," in Confronting Revolutions, ed. Morris J. Blackman, william M. LeoGrande, and Kenneth E. Sharpe (New York: Pantheon, 1986), p. 285.

23 Payne, pp. 164-5.

24 Ibid., p. 165.

${ }^{25}$ payne, p. 165.

26 payne, p. 16.

27 Payne, p. 23.

${ }^{28}$ Dickey, pp. 692-4.

29 Dickey, p. 505. 
CHAPTER IV

\section{NICARAGUA}

During the Reagan Adminstration, Nicaragua, as well as Grenada, have come to represent the communist threat to the rest of the Caribbean Basin and to America. This fear has been reinforced by the Rissinger Commission's report. 1 This bipartisan commission, appointed by the Reagan Administration, asserted that the revolutionary movement opposing the Somoza regime had been seized by self-proclaimed Marxist-Leninists. The Commission further noted that the Sandinista leadership continued to pattern the Nicaraguan government after the Cuban regime. For example, the new government was characterized by mass organizations under its political direction, while an internal security system existed--apparently to supervise the entire population. The Commission also pointed to the massive military establishment which seemed too large for just the needs of Nicaragua. This view of Nicaragua as a threat, as a possible exporting vehicle for Soviet-Cuban communism, has intensified U.S. involvement in the Caribbean Basin. Further, the United States has continued to rely primarily on military policies in attempting to alter the state behavior of Nicaragua. An in-depth examination of these, as well as past U.S. policies, 
is necessary for an effective analysis concerning the utility of U.S. military strategies in the Caribbean Basin.

\section{POLITICAL BACKGROUND}

AND EARLY U.S. RESPONSES

\section{Early Foreign Intervention}

Nicaragua has a long history of intervention. The country was under Spanish influence since 1523, although the Carib Indians along the Miskito Coast (along the Atlantic) remained under British control until the $1800 \mathrm{~s}$.

The history of U.S. intervention can be traced back to the 1830s. At this time U.S. businessmen started formulating plans to construct an interoceanic canal across Nicaragua. This early canal proposal ultimately failed, but the United States continued to show interest in this country.

U.S. policies in regard to Nicaragua became more militant. In 1854 the U.S. Foreign Ministry in San Juan del Norte had been attacked by Nicaraguans after an anti-United States protest. The United States responded by having the U.S. warship Cayne fire upon that Nicaraguan port. The United States also militarily intervened in Nicaragua other times in the 1850s: $1850,1853,1854$ and $1857 .^{2}$

In 1855 an American adventurer, William Walker, declared himself president of Nicaragua. The investor Cornelius Vanderbilt eventually forced Walker to surrender to the U.S. Navy. Although Walker was a private citizen, he was 
viewed by many as "a symbol of U.S. expansionism." ${ }^{3}$ This impression was reinforced by Walker's subsequent actions. seeking to once again gain influence, Walker conducted two more military excursions in the Central American region, although he was finally captured and killed by the Hondurans. The United states did not interfere in Nicaragua again until 1910 when the Taft Admnistration actively aided a Conservative Party revolt against president Zelaya whose nationalism threatened the perceived interests of the united States. The U.S. Marines remained intermittently in Nicaragua throughout the following twenty years. 4 "Although the numbers of marines were small, they were able to effectively control national policy." 5 An example of this control was the link between the military and economic policies. Bolstered by the presence of the Marines, U.S. financial advisers administered the nation's financial policies--even to the extent of creating the cordoba as the national currency. During this early period, United states power was at first maintained by its own military presence. However, over time a privileged elite developed who profited from the occupation, thereby lending its support to U.S. preferences. 6

The U.S. forces left Nicaragua in 1925 but returned the next year to enforce a political settlement; this event led the United States into confrontation with Augusto César Sandino. Sandino opposed the American presence and organized 
a peasant army to oppose U.S. forces. "The war proved indecisive on the ground and unpopular in the United states, forcing American withdrawal in 1933."7 The principal legacy of the U.S. Occupation was the National Guard which was a military force trained by U.S. Marines and placed under the pro-U.S. officer Anastasio Somoza Garcia, with the hope that the guard would "keep peace and protect U.S. interests" in the area. 8

Sandino remained an important political force in Nicaragua, until he was murdered in 1934 at the order of the commander of the American trained National Guard, Somoza. ${ }^{9}$ In 1936 Somoza pressured his main competition Sacasa into resignation, assuming direct control of Nicaraguan affairs. However, the United States still desired to influence events in Nicaragua. Therefore, the United States maintained close relations with the Somoza regime. The degree to which the United States felt secure about its influence over the American-educated and supported leader is indicated by Franklin Roosevelt's famous phrase (referring to Somoza) that he was: "Our son of a bitch." 10

Somoza continued to consolidate economic and political power, establishing a military dictatorship. Somoza was shot in 1956 and died from his wounds. However, his sons--first Luis Somoza Debayle, and then the younger son Anastasio Samoza Debayle--continued the Somoza dictatorship. 
The Seeds of Revolution ${ }^{11}$

The somoza regime was increasingly beset by problems. Although the insurrection leading to the downfall of Anastasio Somoza Debayle was initiated by events in the 1970 s, it was more fundamentally caused by inequities that had developed during previous decades. These problems included export dependence on a sometimes fluctuating world market, peasants who had been forced off land that was desired for export production, and severe problems of unemployment. The severity of the Nicaraguan situation can be indicated by the fact that during the last twenty years of Somozan rule the GNP increased, but the rate of childhood malnutrition grew. Clearly benefits were not evenly distributed; military force was utilized to support the status quo.

The situation which precipitated a crisis for the Somozan rule was a massive earthquake which destroyed much of Managua in 1972. Thousands of Nicaraguans suffered facing even more hardships as the somozan government siphoned off millions of dollars that had been intended for international relief. Resentment over this situation fueled desires for reform.

The Somozan regime increasingly became opposed. More moderate groups included broad alliances of business, labor and political organizations which opposed the Somoza dictatorship. These groups fought Somoza with declarations, 
petitions, and negotiations--as well as with demonstrations and strikes. The radical opposition was led by the Sandinista de Liberacion Nacional (FSLN). This group sought major social and economic change:

The Sandinistas shared the Marxism that was common in the anti-regime student-political milieu from which most FSLN leaders came, and they were inspired by the young Cuban revolution. Some were connected with the Moscow-oriented Nicaraguan Socialist Party (Partido Socialista Nicaragüense-PSN). However, Sandinista ideology was and remains ill-defined, heterodox and pragmatic. From the beginning, party programs spoke of preserving a place for private enterprise within a planned economy. Catholic radicals gained positions of prominence among the leadership, a situation unjmaginable in an orthodox Marxist-Leninist party.

Nevertheless, after years of U.S. influence in the Somoza regime the United states viewed the new situation with alarm. In particular, the Carter Administraiton stuggled to find appropriate policies to deal with this situation.

\section{Carter's Response}

Under the Carter Administration the United States had struggled to maintain influence in Nicaragua. Yet Carter had professed interest in promoting human rights and exploring peaceful strategies. In fact, this policy seemed to have been pursued in 1977 when military aid to the Somozan regime was halted in response to the alleged brutality and repression of the National Guard.

However, the Carter Administration still relied on military pressure to gain U.S. desired goals. For example, it has been reported that during the rule of Somoza, Carter 
had signed a presidential "finding" that "covert action by the CIA was needed in Nicaragua" for the "national security" of the United States. ${ }^{13}$ And, by mid-1978 the United States provided $\$ 12$ million in economic aid to Somoza, claiming that the regime no longer had severe human right violations. 14 "By appearing to re-endorse Somoza, Carter inadvertently undermined the moderate opposition and increased support for the FSLN. " 15

After the popular uprising of September 1978 the Carter Administration appeared to accept that the Somozan regime could not be maintained. At that point, the United states initiated a series of actions designed to replace Somoza and to develop a working relationship with moderate reform elements inside Nicaragua. When the Carter Administration failed at these attempts, the U.S. suggested an O.A.S. peacekeeping force for Nicaragua. This also failed, being viewed in fact as "a facade for armed intervention to forestall a Sandinista victory" and to maintain the key elements of the Somoza regime "without the dictator." 16

The Sandinistas continued to solidify their control in Nicaragua. And on July 19, 1979, the few remaining members of the Somoza regime were evacuated from the country. The initial composition of the new government reflected a variety of political forces.

The Carter Administration attempted to develop a positive relationship with the new government. United States 
negotiators met with Nicaraguan officials and aid was extended to Nicaragua. For example, during Carter's last year in office several million dollars of loans were made to Nicaragua and Nicaragua renegotiated a debt of almost $\$ 490$ million. 17

However, tensions existed between Nicaragua and the United States. The American policymakers were concerned with the growing exclusion of moderates, with the increasingly strident Marxist-Leninist statements, by the eventual emergence of Daniel Ortega as the Nicaraguan leader, and by the growing fear that the Sandinistas intended to support similar revolutions throughout the Caribbean area.

These tensions would be exacerbated during the Reagan Administration. In fact, Ronald Reagan's election to the presidency in November 1980 marked a shift in U.S.-Nicaraguan relations. 18

REAGAN AND THE ATTEMPTED COMMUNIST ROLLBACK

Early Reagan Policies

Ronald Reagan "had run on a party platform that, in thinly veiled language, urged support for efforts to depose the Sandinistas;" yet, the new Reagan administration did not immediately reorient U.S. policies. 19 For example, Ambassador Pezzullo who had been closely associated with Carter's philosophy, kept his office until $1981 .^{20}$ 
Early Use of Threats. However, by 1981 the U.S. interactions with Nicaragua were becoming more menacing. Concerned about reports that the Nicaraguans were supplying arms to El Salvadoran rebels, the United States demanded that such aid be halted. In spite of reports that Nicaragua was indeed halting or substantially reducing such shipments, the U.S. Government stated in April 1981 that no more financial aid--or wheat sales--would be continued. 21

In July 1981 the Sandinistas announced more socialistic measures, including a decree expropriating thirteen major private firms; the United States responded to this situation by initiating a series of diplomatic talks, with Assistant Secretary of State Thomas Enders representing the United States. In retrospect, U.S. interactions with Nicaragua at this time can be viewed as involving military threats to the Sandinista government, even though such threats were "disguised as diplomatic initiatives." 22 For example, under Enders sponsorship, the United States implied that if the Sandinistas were more "cooperative," the United States would sign a nonaggression pact with Nicaragua and that the United States would disband "the camps in Florida where Nicaraguan exiles were training to overthrow the Sandinista government." 23 The obvious threat was that the United States would continue such activities if the Sandinistas proved uncooperative. Seemingly Enders was willing to use military policies to influence the situation. However, 
"Enders sought to use the immense U.S. power as a stick to shape negotiations rather than as a club to drive the Sandinistas and FMLN into oblivion." 24 These threats were not "well-received," with Nicaragua seemingly determined not to alter its state behavior as a result of U.S. threats. 25

In November of 1981, Alexander Haig, then Secretary of State, testified before the House Foreign Affairs Committee. Haig continued to present a threatening posture by refusing to dismiss the possibility of a military blockade of Nicaragua or assistance to the Nicaraguan exiles trying to overthrow the Sandinista government.

Attempts at Credibility. In November 1981, backing previous threats with credible actions, the National security Council (NSC) decided to implement a larger scale program to deal with opposition to U.S. policies in the Caribbean Basin. The program included:

... subversive operations inside Nicaragua, support for paramilitary operations against the Sandinistas from the outside, economic pressures, military threats, contingency planning for military intervention, increased intelligence activity, propaganda efforts, more military aid to El Salvador and more pressures on Cuba, and jojpt planning with America's friends in Latin America.

In November the United States also attempted to reinforce its credibility by conducting large naval exercises in the Caribbean (READEX-I) "as a warning to Nicaragua." 27 These exercises involved other NATO countries, presumably sending an even more credible threat to Nicaragua. 
Debate Regarding U.S. Policies. This reliance upon military strategies was alarming to many. In the summer of 1982, during CIA briefings, Congress was informed that U.S.-supported contras had destroyed two major bridges inside Nicaragua in March, and that the "supposedly limited commando forces had grown to 15,000 soldiers" who were preparing to relocate some of their camps from Honduras to Northern Nicaragua. The legality of these activities was questioned and the fear of a war between Honduras and Nicaragua--started by the CIA and the contras--grew. In response to these concerns (August, 1982) Congress amended the secret intelligence bill, setting clear limits on U.S. covert operations in the Caribbean Basin. 28

Yet, American policy was still not clearly defined regarding the reliance upon military strategies. 29 In December 1982 Congress had "publically approved" the Boland Amendment which specifically prevented the Reagan Administration from financing the contras for the purpose of overthrowing Nicaragua's government. However, various policy makers insisted that enough force was needed to achieve "symmetry". To these officials symmetry meant that the contras, with U.S. backup would respond to any Nicaraguan military action with a similar strategy of their own. The concept of symmetry permitted the Administration to argue, however, that it was only acting toward Nicaragua as Nicaragua acted toward others, even though the contras Reagan 
funded in Nicaragua declared openly their goal was to overthrow the Sandinistas. 30

Certain U.S. policy makers, then, favored using military strategies; however, just as they had to contend with a reluctant Congress, so they had to contend with a regional group which sponsored negotiation rather than confrontation. In January 1982, a group of countries-Mexico, Venezuela, Colombia and Panama--met on the Panamanian island of contadora. These countries became known as the Contadora group, and seemed to promise an alternative to U.S. military solutions. This complicated the use of military policies by the United States. The Administration needed to appear as if it were responsive to negotiations if it hoped to stay on good terms with congress. The tension between choosing between military strategies or negotiations is evidenced by the fact that Reagan was careful to appeal to both factions. When President Reagan addressed a joint session of Congress on April 27th, he announced that "we will support dialogue and negotiations--both among the countries of the region and within each country." ${ }^{31}$ Yet, Reagan also called for increased economic and military aid "to bolster humane democratic systems" and respond to "the military challenge from Cuba and Nicaragua." 32

By the spring of 1983 there was more debate as to the degree of military influence that ought to be exerted. It was becoming clear that halting guerilla activity in 
El Salvador would not be an easy task. Further, Nicaragua continued to establish closer ties with the cubans and Soviets. Administration officials became even more concerned that Nicaragua could serve as an attractive model for other Marxist/socialist revolutions, as well as offering military support to such groups. "By May there was plainly an intense debate within the Administration over whether it should go beyond its existing program of 'covert' aid to antiSandinista guerillas, to threaten Nicaragua more directly with the application of direct U.S. power." 33

\section{Continued Threats and Military strateqies. The} increasing U.S. reliance upon military strategies is clearly evidenced by U.S. activities which began in early July 1983. At this time large-scale joint military maneuvers between the United States and Honduras were announced.

Although the Reagan Administration initially presented these joint military maneuvers, called the Big Pine II maneuvers, as routine--these military exercises seemed clearly designed to influence the Sandinistas to alter the state behavior of Nicaragua. Part of the exercise included naval activities. These exercises included a naval show-of-force by the United States. However, U.S. Forces were so great that it could be argued these forces were meant to do more than just display power, they were meant as a threat. For example, two separate naval forces, including U.S. warships and aircraft carriers, were sent by the United 
States and were assigned to each side of the Nicaraguan coast. The threatening nature of this U.S. action is clear when one considers that:

The destructive force represented by the guns and planes carried on these two armadas is phenomenal: It should be noted that at no time did the United States deploy as much naval-based fire power in Southeast Asia throughhout the entire course of the vietnam war.

Furthermore, the nature of the exercises was threatening. During these exercises the Navy practiced blockade techniques. 35 And, Marines stated a practice amphibious landing on the nearby coast of Honduras. 36 Aside from the naval activities, American personnel were also stationed in several neighboring countries near Nicaragua. The threatening nature of the American troops can be evidenced by their close geographical proximity to vicaragua. For example, one group was sent to a "narrow strip of land near the Gulf of Fonesca that separates El Salvador and Nicaragua." 37 Another naval crew was ordered to dig wells in Guanacaste--a northern Costa Rican province which is just "a few minutes drive" from the Nicaraguan border. 38

These exercises, then, involved a display of U.S. force which was an attempt to communicate a threat, thereby influencing Sandinista behavior. The threat was communicated by the U.S. actions themselves. Aside from the nature and location of these military maneuvers, the scope of these exercises were larger than earlier maneuvers--presumably, 
this could communicate a stronger message to the Sandinistas. And, these exercises were designed to last months, rather than just the days or weeks of previous U.S. maneuvers. 39 In fact, so many thousands of Americans were involved that the Big Pine II exercises could be considered as "nothing less than a temporary stationing of U.S. armed forces in the Isthmus." 40

The United States did not rely entirely on its actions to communicate its displeasure to Nicaragua. More threatening statements were made. Top Reagan Administration officials publicly stated that unless Cuba halted shipments to Nicaragua, President Reagan "had not ruled out establishing a military quarantine around Nicaragua." 41 other "unnamed Administration officials" repeated strong statements to the popular press, such as the statement found in a Time magazine: "We want to persuade the bad guys in Nicaragua and Cuba that we are positioned to block, invade, or interdict if they cross a particular threshold." 42 Furthermore, during this period of time, U.N. Ambassador Jeane Rirkpatrick talked "openly about the possibility of interdiction," and when asked if the naval maneuvers were showing the Sandinistas that the U.S. could blockade Nicaragua, Rirkpatrick replied, "Maybe. Maybe we' 11 remind them of that." 43

There is some evidence that U.S. Forces served more of a purpose than "gunboat diplomacy" and coercion, that they actually served a military function, thus representing an 
escalation of force. The contras were supported by the United states and therefore benefited from the U.S. troop presence. In fact, U.S. troops "acted as a shield to protect contra forays across the Nicaraguan border;" and it can be argued that "it was no accident that upsurges in contra acton did occur" during these exercises. 44

By the end of 1983 it was clear that the United States had continually increased its reliance upon military strategies. Big Pine II represented the largest maneuvers conducted by the United States, larger even than naval displays in Vietnam during that war. Known United States armed forces in the area had increased from 500 in December 1981 to about 15,000 in late $1983 .{ }^{45}$ originally, President Reagan approved a $\$ 19.5$ million program of funding covert activities in Central America, for the stated purpose of "stopping Nicaraguan arms shipments to Salvadoran and other Central American rebels. "46 Budgetary arrangements for funding subsequent operations have not been entirely clear. However, a press report has referred to the United States Congress as having approved about $\$ 20 \mathrm{million}$ for 1983 , and in November 1983, legislation was adopted that no more than $\$ 24,000,000$ was to be allocated for military or paramilitary actions in Nicaragua. 47

Evaluation of Early Policies

The United States has clearly relied upon military strategies in dealing with Nicaragua. President Carter made 
some attempts to shift the focus of U.S. policies; but the Carter Administration did not maintain a consistent approach to Nicaragua, relying intermittently upon military strategies when they seemed needed. When Nicaragua did not appear to be responding to veiled military threats (such as the ones referred to in 1981 regarding the camps in Florida), the United States used more direct threats, and attempted to support these verbal statements by concrete actions to make these threats even more credible. During the Reagan Administration United States policymakers resorted even more to military strategies. Such heavy reliance upon military policies has lead one analyst to write that the United States has used military options as a substitute for state policy, with diplomacy and politics being replaced by threats and military escalation. ${ }^{48}$

\section{Camouflaged Tactics and Information. Since much} information regarding Nicaragua is classified, it is not an easy task to evaluate U.S. military policies in Nicaragua. Clearly it would often be a disadvantage to openly discuss the underlying reasons of U.S. negotiation strategy--or to state that a military maneuver was designed only as a bluff. Furthermore, military policies have been of a covert nature. Therefore, there are innumerable difficulties in documenting such U.S. military involvement. It is known that the United States has provided military weapons to "friendly" countries, countries which are willing to oppose Nicaragua. 
For example, in March 1982 the United States provided 10 Bell UH-1H helicopters to Honduras. These planes were provided at no cost to Honduras under a special lease program. 49 American personnel were needed to provide training regarding these helicopters. However, the numbers of U.S. military personnel have been hard to track. By 1982 a Pentagon spokesman stated that a number of U.S. military personnel had trained the Hondurans in technical areas as "helicopter maintenance and air base security," but he added the number of U.S. personnel have changed "too frequently for us to keep tabs," and a specific breakdown of the U.S. trainers and their function was "unavailable." 50 Not only have there not always been clear indications regarding the exact number of Americans involved in suport of other country's military policies, but there have not always been clear indications as to the exact scope of these American personnel. For example, the Green Beret Special Forces were reportedly in Panama as advisors. However, in 1981 they were reported as having actually been seen patroling the border between Panama and El Salvador, dressed in camouflage and carrying Ml6s. 51

Another incident explains how the Administration has attempted to avoid Congressional oversight and restrictions, but also indicates the difficulty of accurately reporting U.S. military involvement in the region. 52 Normally, to provide funds to build bases or provide military supplies to a foreign government, the American government first must 
obtain the consent of Congress, "a consent which has been increasingly difficult to achieve." Yet the United States military constructed a base at Durzuna claiming it was needed to conduct U.S. military exercises there. When the exercises were over, the military equipment that had been funded for U.S. military maneuvers was simply left behind--for contra use. Since this money and equipment does not appear in any category of U.S. security assistance to Honduras, it serves to hide the true amount and proportion of military aid that the public knows about.

Unwilling to appear as an aggressor and restrained by a Congress which became increasingly hesitant to rely upon military straegies, the United States policymakers encouraged other countries sympathetic of the U.S. stance to aid the contras. In mid-1983 Israel was "persuaded" to supplement U.S. military aid by sending weapons captured in Lebanon to officials in the Honduran government--weapons that would be distributed eventually to the contras. 53

Restricted Options. Since information regarding U.S. military strategies has often been restricted and since publicized satements have often been made for effect (as with threats) a certain amount of speculation is involved in analyzing U.S. policies.

However, it is clear that over a period of time, U.S. policymakers who favored stronger U.S. actions gained prominence within the Reagan Administration. For example, in 
the early 1980s policy toward Nicaragua had largely been in the hands of the state Department--specifically, under the direction of Thomas Enders. Enders came to develop strong views regarding the Nicarguan situation; he has been reported as finally viewing the situation there "as not warranting direct U.S. military intervention." 54 Rather, Enders favored isolation and containment of the Nicaraguan government, with emphasis on seeking a negotiated settlement. 55 However, Enders' approach was disputed by others, especially by then National Security Advisor William P. Clark and Jeane Kirkpatrick, then U.S. Ambassador to the United Nations. 56 Enders was eventually replaced by Langhorn Motley whose early views reflected reliance upon military strategies. 57 However, over a period of time, Motley preferred policies which sought alternatives to military force or threats. In fact, Motley decided that "United States military escalation created the opposite results that it had set out to achieve." 58

Still, the Reagan Administration did not appear to fully explore policies other than military ones. Specifically, it has been suggested that the Reagan Administration "used diplomatic discussions as a fig leaf for military escalation." 59 For example, it has been suggested that Nicaragua did experience political and economic pressures due to the activities of the U.S.-supported contras; and that by July 1982 the Sandinista regime did 
alter its behavior by relaxing media censorship and by presenting new draft proposals to the Contadora countries; these actions can be viewed as "conciliatory" gestures which clearly signaled that it wanted "to reach accomodation with the United States." 60 However, the Reagan Administration has been criticized because it did not "test or explore the Nicaraguan gambit," but instead continued to ask for more concessions from Nicaragua. 61 In fact, U.S. policies seemed to consist of tactics of "sanctions and pressure." 62 Just as the United States restricted its own domestic policy options, it also did not fully explore contadora regional peacemaking efforts. United states reluctance regarding the Contadora proposals may have stemmed from U.S. hesitation to participate in a rather unpredictable negotiation process. 63 A National security document from the time of these negotiations has been made public; it revealed the United States had a deep mistrust of the Mexicans and their approach to the region, which tacitly implied some political particpation for the socialists in El Salvador and the Sandinistas in Nicaragua. 64

Risk v. Effective Policy. There is some evidence which suggests that U.S. military strategies did have an impact on Nicaragua. For example, by September 1983 Nicaragua "seemed more responsive to the negotiating efforts presented by the contadora groups." 65 The Sandinistas also attempted to placate other states by removing several Cuban 
advisors, lightening their censorship of the press, and making statements regarding the importance of a fair electoral process. ${ }^{66}$ To some it seemed that "gunboat diplomacy" so concerned the Sandinistas that they decided to radically change tactics." 67 . Specifically, the Big Pine II exercises were considered by government officials to be an effective communication of U.S. intentions, responsible for the altered state behavior of Nicaragua. 68

The state behavior of the Soviet Union and Cuba also altered. Castro now offered to "work out a deal with President Reagan to pull out all foreign military advisors from Central America." 69 And, during a naval incident, occuring within a week of the Big Pine II exercises, the Soviets were "unusually restrained;" they "clearly shied away from a confrontation with the U.S." 70 It was considered that this Soviet caution may have been due to "the Reagan Adminisration's evident disposition to use force to shore up the American sphere of influence. 71

State behavior of Nicaragua, Cuba and the Soviet Union did alter; however, the evidence is suggestive rather than conclusive regarding the cause for the changed behavior. The tentative nature of these findings is partially due to a restricted amount of available information concerning the subject. The altered actions could have been influenced by factors, other than coercion. For example, altered actions could have been designed for Nicaraguan propaganda value, 
with the United States portrayed as an aggressive and militaristic nation, as contrasted to Nicaragua, a nation trying to present itself as reasonable, as interested in negotiations. Or, Nicaragua and cuba may have been sincerely seeking an accomodation with their neighbors. For example, now that the Sandinistas had gained political control they may have desired to strengthen and solidify their programs within Nicaragua rather than becoming more involved with regional reform movements. The Soviet Union may not have been affected by coercion either. The Soviet Union may simply have been preoccupied with internal matters, such as the illness or succession of new leaders. Or, the soviet Union may simply have restricted its policy voluntarily. Involvement in both Afghanistan and the Caribbean (with the Caribbean representing even more of a financial commitment due to its distant geographical location) could have been considered unwise from an economic viewpoint.

Regardless of the true reason for altered state behavior, the Reagan Administration interpreted Nicaraguan, Cuban and Soviet rections as an indication that U.S. military strategies had been successful. ${ }^{72}$ Rather than pursuing unpredictable negotiations which possibly could accord socialists some legitimacy, the United States viewed military strategies as a more controllable approach to the region's problems. ${ }^{73}$ when Nicaraguan actions appeared "as a sign they were buckling under" these strategies seemed successful; 
to many U.S. policymakers it became imperative for the United States "to increse the pressure" on the Sandinistas even more. 74

Even if the use of military force was successful in altering the behavior of states as a consequence of the Big Pine II exercises, it is still questionable whether the United States ought to rely upon such strategies. As pointed out previously in the historical section of this paper, United States influence and intervention has been resented. There already exists "anti-Yankee" sentiment and recent U.S. responses only strengthen such attitudes. For example, in mid-August of 1983, President Miguel de la Madrid (Mexico) cautioned Prsident Reagan against aggravating existing problems through U.S. "shows of force." 75

Aside from such reactions, U.S. military policies involve a certain amount of risk. There is always the danger of escalation, even the risk of war. For example, within one week of the Big Pine II naval maneuvers an incident occured which could have led to an escalation of military forces. In this incident "a U.S. destroyer harassed a Soviet freighter by demanding to be told its cargo and destination, then shadowing it for the next forty miles until it turned into Nicaraguan territorial waters to enter corinto, the nation's largest port."76 while this incident demonstrated the resolve of the United States it can also be considered as 
"brazen and reckless" and could have led to a situation as serious as the confrontation between the United States and the Soviet Union in the Cuban Missile Crisis. ${ }^{7}$ During this same period of time, former vice-President Mondale warned that escalation would occur: "...under present policies it is inevitable that American troops will be sent to Central America... 78

There was also the problem of planned operations exceeding their original limits. Reporters in Newsweek magazine claimed, in fact, that operations along the Nicaraguan-Honduran border "have escalated far beyond Washington's original intentions." 79 The involvement of the United States in the support of the contras has provided a particular problem. There was the question of how much control the planners in Washington or the U.S. advisors in the field actually had concerning the military force used by the contras. For example, in May 1983, one of the contras, Pedro Pablo Ortiz Centeno who called himself "Commander Suicide," went on a personal rampage. This illustrated but one aspect of the difficulty involving the control of the contra forces. One analyst wrote that the forces backed by Washington must be under tight control, "But the actions of Suicide suggested they were under little or no control. 80 Regardless of the possible negative impact of U.S. military strategies in the Caribbean Basin and regardless of the actual risk involved in these actions, the United states 
continued to employ military strategies to try to influence and coerce Nicaragua into state behavior that would be more acceptable to the United States.

\section{REAGAN AND THE MINING OF THE NICARAGUAN HARBORS}

By 1984, there was no improvement between the United States and Nicaraguan relations. While the Sandinistas had made certain negotiating suggestions previously, by 1984 "the Sandinistas had taken about as many conciliatory steps as they were likely to be willing to do." 81 They also verbally indicated their belief that the Reagan Administration would not be satisfied until they gave up so many principles "that they stopped being Sandinistas." 82

Even while continuing its participation in the negotiating process, the United States continued to rely upon military policies. This time a stronger policy was devised, designed to presumably send an even stronger message to Nicaragua. By November 1984, the Reagan Administration focused less on the shipment of arms by Nicaragua to other countries (possibly because there was little proof regarding these activities). Increasingly, the Administration spokesmen began insisting that "major changes in the basic nature of the Sandinista regime itself" occur. ${ }^{83}$ And, the United States became involved in the laying of mines in or close to various Nicaraguan ports. 


\section{The Course of Events}

official information regarding these incidents has not been clearly documented. However, U.S. involvement in the mining incidents seems well substantiated. 84 U.S. press reports quote U.S. administration officials as saying that mines were constructed by the CIA with the help of a United States Navy Laboratory. Another press report indicated that it was announced in the U.S. Senate that the CIA Director informed a select intelligence committee that president Reagan had approved a plan for the mining of Nicaraguan ports. President Reagan later revealed knowledge about the mines in another press report, although he claimed Nicaraguan rebels had laid the mines. Still other press reports from top Reagan officials stated that the "mother ships" used for the operation were operated by U.S. nationals.

Nicaragua complained about such military activities to the United Nations Security Council. However, through its use of the veto, the United States was able to prevent any action favorable to Nicaragua. 85

Then, in April 1984 Nicaragua applied to the International court of Justice (ICJ) for relief. In spite of United states arguments opposing the Court's jurisdiction, the ICJ found it had jurisdiction to try this case. The Court did try the case, without U.S. participation in pleadings or oral arguments, and decided on June 27,1986 in favor of Nicaraguan claims. 
The ICJ Judgment

In Nicaragua $v$. United States of America the ICJ agreed that the United States had been pursuing military policies in regard to Nicaragua. The Court noted that it was indeed difficult to evaluate the facts and evidence regarding the alleged incidents. The united states did not admit to the military activities and, as noted, information regarding these events was limited. The ICJ relied upon the previously mentioned press reports for its judgment against the United States. The court also noted that in a previously filed Counter Memorial, the United States had referred to the fact it had taken certain measures in self-defense. While the United States did not list specific facts regarding these self-defense measures, the court noted that the normal purpose of mentioning self-defense is to justify conduct which would otherwise be wrongful: "The court thus cannot consider reliance on self-defense to be an implicit general admission on the part of the United States: but it is certainly a recognition as to the imputability of some of the activities complained of $\$ 86$

Specific U.S. Military Actions. The Court was very specific regarding the United States military involvement in its final judgment. For example, Paragraph 80 states: 
...the Court finds it established that, on a date in late 1983 or early 1984, the President of the United States authorized a United States government agency to lay mines in Nicaraguan ports; that in early 1984 mines were laid in or close to the ports of El Bluff, Corinto and Puerto Sandino, either in Nicaraguan internal waters or in its territorial sea or both, by persons in the pay and acting on the instructions of that agency, under the supervision and with the logistic support of United States agents; that neither before the laying of the mines, nor subsequently, did the United States Government issue any public and official warning to international shipping of the existence and location of the mines; and that personal and material injury was caused by the explosion of the mines, which also cregted risks causing a rise in marine insurance rates.

In addition to the laying of mines, the court also found the United States was implicated in other military activities, including:

(1) 10 October 1983: an attack was made by air and

sea on the port of Corinto, involving the destruction of five oil storage tanks, the loss of millions of gallons of fuel, and the evacuation of large numbers of the local population;

(2) I4 October 1983: the underwater oil pipeline at Puerto Sandino was again blown up;

(3) 3/4 January 1984: an attack was made by speedboats and helcopters using rockets against the Potosi Naval Base;

(4) 7 March 1984: an attack was made on oil and storage facility at San Juan del Sur by speedboats and helicopters;

(5) 28/30 March 1984: clashes occurred at Puerto Sandino between speedboats, in the course of minelaying operations, and Nicaraguan patrol boats; intervention by a helicopter in support of the speedboats;

(6) 9 April 1984: a helicopter allegedly launched from a mother ship in international waters provided fire suppoft for an ARDE attack on San Juan del Norte. 
After examining further Nicaraguan complaints regarding U.S. violations of Nicaraguan airspace, and U.S. support of the contras, the court did find the United states had conducted high-altitude overflights, and two lower flights which resulted in sonic booms, with these incidents occurring from November $7-11,1984 .^{89}$ It was also concluded that U.S. citizens, both military and nonmilitary provided assistance to the contras in these incidents. 90

Specific U.S. Violations of International Law. The Court declared these U.S. military strategies violated international law in several respects. Not only were specific treaties violated, but the court concluded that the United States also had acted contrary to the general customs and principles of international law.

While the court did not find that the United states "controlled the contras to the degree that the United States would be legally responsible for all illegal contra acts," the Court did find that the U.S. support of the contras was "a clear breach of the principle of non-intervention." 91 The Court observed that no evidence existed that the United States was responsible for the creation of the contra force. According to the court: "It seems certain that members of the former Somoza National Guard, together with civilian opponents to the Sandinista regime, withdrew from Nicaragua soon after that regime was installed in Managua, and sought to continue their struggle against it..." 92 Yet, the court 
determined that over the years the U.S. support for the contras grew:

However, it is in the court's view established that the support of the United States authorities for the activities of the contras took various forms over the years, such as logistic support, the supply of information on the location and movements of the sandinista troops, the use of sophisticated methods of communication, the deployment of field brodcasting networks, radar coverage, etc. The court finds it clear that a number of military and paramilitary operations by this force were decided and planned, if not actually by United States advisors, then at least in close collaboration with them, and on the basis of the intelligence and logistic support which the United States was able to offer, particularly the supply aircraft provided to the contras by the United States.

still, the court stated there was "no clear evidence of the United States having actually exercised such a degree of control in all fields as to justify treating the contras as acting on its behalf." 94 As a result of this latter conclusion, the court did not find the United States guilty of humanitarian crimes committed by the contras.

However, the Court also found that the United states had intervened in Nicaragua contrary to the principles of international law. The court noted that the United States policy toward Nicaragua "has consistently sought to achieve changes in Nicaraguan policy and behavior." 95 Further, the Court found that the United States was well aware of the contras' intentions to overthrow the Nicaraguan government. 
The court therefore found:

...the support given by the united states, up to the end of Septemer 1984, to the military and paramilitary activities of the contras in

Nicaragua, by financial support, training, supply

of weapons, intelligence and logistic support, constitutes a clegg breach of the principle of non-intervention.

Such actions were also "in breach of its obligation... not to use force against another state." 97

The court noted that the United States had attempted to justify its support of the contra actions by claiming the Sandinista government was repressive. The United States claimed tha Nicaragua had taken "significant steps towards establishing a totalitarian Communist dictatorship; " but the Court found that even if this were true, it would not open up "a right of intervention by one state against another on the ground that the latter has opted for some particular ideology or political system." 98

Furthermore, the court claimed the U.S. laying of the mines also violated customary international law. For example, this action was an abridgement of Nicaragua's freedom of communication and maritime commerce. ${ }^{99}$ And, by directing or authorizing overflights of Nicaraguan territory, the United States was found to have acted "in breach of its obligation under customary international law not to violate the sovereignty of another state." 100

While the court did not find the United states guilty of violating international humanitarian law, it did note that 
the United States had acted contrary to the principles of humanitarian law by producing and distributing a 1983 manual entitled: "Psychological Operations in Guerilla Warfare." The Court did not find evidence specifically linking the United States to humanitarian crimes, and it was noted that the CIA later attempted to modify the effect of this pamphlet. Yet, the Court felt the document must still have served as an "encouragement" to those who would "commit acts contrary to general principles of international humanitarian law reflected in treaties." 101

The court noted even more U.S. violations. The laying of mines, and interference with the freedom of the seas was a breach of customary international law. The court also stated the United States had violated provisions of the United Nations Charter, the OAS Charter, and the United States had acted against its promised obligations in its Treaty of Friendship, Commerce, and Navigation which both the United States and Nicaragua had signed in 1956.

The Court's Directions to the United States. The Court clearly stated United States military policies were not acceptable. As a result of U.S. violations of international law, the court decided that: 
(1) ...the United States of America is under a duty immediately to cease and to refrain from all such acts as may constitute breaches of the foregoing legal obligations;

(2) ...the United States of America is under an obligation to make reparation to the Republic of Nicaragua for all injury caused to Nicaragua by the breaches of obligations... ...the form and amount of such reparation failing agreement between the Pafties, will be settled by the court...

The Court also reminded both Nicaragua and the United States of their obligation "to seek a solution to their disputes by peaceful means in accordance with international law. "103

\section{Evaluation of U.S. Actions}

In its involvement with the mining of the Nicaraguan Harbor, the United states relied upon military policies rather than pursuing alternative strategies, such as settling problems through international legal channels. This U.S. emphasis upon military options has had a negative impact upon the international environment, even encouraging anarchical tendencies within the inter- national system. Further, a negative image which already was held by many countries toward the United States was reinforced by these actions.

\section{Failure to Use the ICJ as an Alternative to Military}

Strategies. The United States argued that the ICJ had no jurisdiction regarding the mining of Nicaraguan harbors, that this was a political incident. And, soon after the American refusal to participate in the case, October $7,1985--$ the U.S. Secretary of State, George Schultz, deposited the witharawal from Article 36 (2) of the statute of the 
International Court of Justice (the Optional Clause, voluntarily signed by the united states, granting the court compulsory jurisdiction).

Politics $v$. Justice. In rejecting the compulsory jurisdiction by the Court, the United States State Department insisted:

The conflict in Central America, therefore, is not a narrow legal dispute; it is an inherently poltical problem that is not appropriate for judicial resolution. The conflict will be solved by political and 104 diplomatic means--not through a judicial tribunal.

However, as previously noted the United states has seemingly used diplomatic encounters with Nicaragua as opportunities to make further demands upon that country rather than truly attempting to seek an accomodation. And, in the very political setting of the U.N. Security Council, the United States used its veto power to block Nicaraguan initiatives. Yet, the United States claimed that the court would not represent a fair, impartial standard of truth. Instead, the United states claimed that the ICJ had become politicized. It may be that the United Nations as an organization has become involved in international politics. Many analysts have regarded diplomatic statements as well as U.N. resolutions as biased: "We have seen in the United Nations, in the last decade or more, how international organizations have become more politicized against the interests of Western democracies." 105 And, the fear has existed that the court might become as politicized as the other U.N. agencies. 
Noting the U.S. fear of anti-Western sentiment American jurists have questioned: "...why should a superpower, in matters of essential national interest, ever subordinate its power of initiation to a system that it does not control and that may even be controlled by our enemies?n106 It also seemed unfair for the Untied States to abide by such a possible politicized decision, when other nations of the world had been less accepting of the court's authority. For example, out of 159 member U.N. states, the United States was "one of only 44 states to have accepted the Court's compulsory jurisdiction." 107 And regarding the sixteen judges who were to try the case, Nicaragua v. United States of America, "11 judges were from countries that do not accept the Court's compulsory jurisdiction." 108

The reality is that politics permeate the international environment, affecting even legal processes. Therefore, it would be an error to view politics and international law as separate. 109 Rather, the legal process is often utilized in a political manner: "The controverted versions of international law are parts of the weaponry of political warfare to support adversary claims, not ideas engaged in a contest for truth." 110 And, "states generally conceive their disputes in fundamentally political terms." 111 
Accordingly, it has been argued:

Legal dimensions of international disputes are seen as an extension of the political character of these disputes. As political actors, states are understandably reticent about losing control of the disputes to which they are a party, and this means, in part, that states tend to adhere to their own conceptualization of disputes rather than accept a conceptualization presented from an alternative source.

There have been occasions when the politics asociated with the court have been helpful in creating an atmosphere which fosters the eventual resolution of the international problem. For example, the court can serve political interests by slowing down hostilities, and giving opponents a chance to resolve their differences politically. Continued participation by the United States in the ICJ case:

"...would at least have afforded time for a political settlement of the controversy." 113 The court also can provide an opportunity for countries to publicize their views. Further, the threat of taking a state before the ICJ can also be used as a bargaining maneuver to pressure the other country to compromise. In this sense, "the mere presence of the Court provides one possible means of settling disputes in a peaceful fashion." 114

There have even been occasions when the United States has benefitted from the relationship between 1 aw and politics. For example, the United States has manipulated legal arguments to serve its own political interests. During the Cuban Missile Crisis the United States desired to prevent 
Soviet military supplies from reaching Cuba--but did not want to violate the freedom of the seas, causing an act of war. Analysts, writing about U.S. legal arguments concerning the establishment of a naval quarantine have written: "surely the American concern for international law was not a significant factor" in establishing a naval quarantine of Cuba; rather, "ambiguity in the law simply left room" for the United States to pursue this legal strategy. ${ }^{115}$ And, during the hostage crisis in 1980, the United States benefitted from the diplomatic climate--partly influenced by the ICJ--in which Iran felt compelled to release the American hostages. 116 The court, "acting in a highly politicized environment," was able to influence events in a situation where the employment and threats of U.S. power had "failed utterly" to achieve results. 117

Therefore, it is a misconception to distinguish between law and politics in a dichotomous fashion. Rather, it is necessary to understand the relationship betwen $l a w$ and politics:

...law and lawfulness do not replace politics; they redirect politics by establishing an orderliness to dispute resolution and a content to the dialogue of the dispute. It makes sense to think of the development of lawfulness as a movement along a continuum ranging from power-centered to principle-centered approaches to dispute resolution. Given the current state of international law, it is easy to see that the states of the world still have some way to go along this continuum.

In light of the preceding arguments, it would not seem to have been in the best interests of the United States to 
withdraw from the ICJ case involving Nicaragua. To many nations the U.S. response seemed extreme and reactive. The United States should have remembered that the ICJ had been useful to the United States in the past; "... we should not have walked away..." 119

Power v. Legality. By refusing the participate in a legal process and by withdrawing from the Optional clause, it seemed as if the United States felt more secure relying on military policies to achieve its aims, rather than trusting in the adjudicative process. The United States actions seemed to indicate "that the U.S. interest is better protected when the nation relies on its own power than when it is submerged in a multilateral system which it cannot control." 120 Soon after the United states withdrew from the Court case, President Reagan clearly indicated he would continue to rely upon military policies. In a news conference on February 22, 1985 he stated that until the Sandinista government says "uncle," the goal of U.S. policy "is directly that of removing the 'present structure' of that government." 121 This no doubt seemed a credible threat of force since the United States invaded Grenada soon after President Reagan had once described that government as consisting of "leftist thugs." 122

International legal agreements also do not seem to have restrained the United states from its military policies in Nicaragua. As noted, the ICJ found the United States had 
violated provisions of the United Nations Charter, the OAS Charter, and its Friendship Treaty with Nicaragua. International jurists had hoped the development of supranational institutions and their accompanying international law would restrain the conduct of states in the world, but U.S. actions seem to indicate that "the Organizaton of American States is of only marginal importance if it interferes with the U.S. policy of keeping Communist elites from gaining control of governments in the hemisphere." 123

(U.S. lack of support for any Contadora proposal that would accord legitimacy to leftist governments would seem further substantiation of this argument).

Although there are some moralists who would always eschew the use of force, other analysts would insist that "the structure and stability of a community depend upon both law and power."124 For example, the system of law can be regarded--not as a substitute for force--but as a "summary of the rules through which the society of nations deems it proper that the sanction of force be used to uphold the law." 125 Some analysts even argue that coercion is legitimate:

The nub of the matter is that the word 'coercion' has no normative significance; there is nothing illegal about coercion... Coercion is moral in all human relationships...so is cooperation. Indeed, every human relationship is some mixture of coercion and cooperation. So to say that a particular relationship is coercive $\dot{1}_{6}$ to say nothing at all about its legitimacy. 
Increase in System Instability. The problem with states resorting to military strategies is that this adds to the uncertainty in the international system. If international law seems to allow a certain amount of force to be used (as in self-help, self-defense, retaliation), most states have still faced a basic problem regarding the amount of force needed to achieve state aims. And, "power-seeking alone" may not be "entirely productive of system stability. 127

An example of system instability is the area of customary law. It can be argued that recent U.S. military strategies are affecting international law in a confusing manner. The continued U.S. reliance upon military force may affect customary law by setting new standards for one state's intervention into the affairs of another state. ${ }^{128}$ For example, the U.S. intervention in Grenada which ended the government that had just seized power through force, and the present support for the contras to remove the Sandinista regime in Nicaragua may be influencing a new rule of customary international laws and this new standard seemingly would allow states to intervene in other states possessing "improper" governments. 129

In fact, since the end of World War II there has been an increase in state intervention. There has seemed to be a "new international concern regarding human rights. "130 
Since World War II there has been a revolution in international legal affairs that permits states to intervene on behalf of insurgents within other states who are fighting against obvious regime terror. This revolution has removed a state's sovereignty regarding its own nationals from the claim of domestic jurisdiction whenever such treatment fails to conform to particular normative requirements.

Even though "human rights" and "democratic arguments" are used by the united States to justify its activities in Nicaragua, Nicaragua can turn the same argument around to justify its support for insurgents in El Salvador. Therefore, Nicaraguan intervention in El Salvador "may not be an instance of aggression at all." Rather, following the same emphasis on human rights emphasized by Carter, Nicaraguan officials can argue their "actions toward El Salvador may qualify as 'humanitarian intervention." "132 In new customary law, then, it could be argued that: "Intervention can be both permissible and required."133 seen from this perspective, recent U.S. military policies may not only be influencing events in the Caribbean, they may be influencing the direction of international relations. And, the new direction of international behavior may be less ordered by restraint. Analysts have warned: "By acting on the timedishonoured assumptions of political 'realism' the United States will enlarge the arena of worldwide instability."134

Another example of system instability regards "spheres of influence." While rules of international behavior could not be considerd standardized, there are analysts who have 
claimed that several years ago there seemed to be tacitly understood rules regarding superpowers and their regional conflicts. This understanding regarded spheres of influence, with the idea that each superpower could intervene in its own sphere of influence, but it would refrain from intervening in the other's area of dominance. However, this tacit understanding no longer holds true. In the present day, the interests of each power are now worldwide, as reflected by U.S. suport for Afghan rebels, and U.S.S.R. assistance to Nicaragua. At present, therefore:

There is little consensus between the superpowers on the principles that should be applied in negotiations on regional conflicts, and little consistency in the approach that each has taken in addressing the varous confligt situations in which it has become involved.

Following international law and pursuing other order-seeking strategies could "do much to counteract the uncertainty" associated "with power-seeking strategies." 136 Specifically, the rules of international justice provide a general outline for promoting order-seeking strategies; therefore:

... it seems reasonable to place great weight on their importance in the course of a state's foreign policy-making. A state which fails to respect these international norms will incur difficulties in managing international uncertainty in the best interest of its citizenry. 137

It would be in the best interest of the United States, then, to respect international customs and laws in order to 
help reduce international tension. These rules of international justice provide a general outline for promoting order-seeking strategies; in fact, these strategies are essential for the effective management of international uncertainty. 138 Thucydides noted that "the strong do what they have power to do and the weak accept what they have to accept."139 However, such behaviors only increase international uncertainty, with the risk of military strategies escalating. Observing this, Richard Falk has written: "The world may not have much time left in which to establish an effective system of world law." 140

In spite of the inherent destruction associated with military confrontations in the international environment, it should be emphasized that the development of international order is an evolutionary process, one that will take time. Most analysts agree that the International Court of Justice is still "far from attaining a centralized judicial authority."141 In fact, the international community can still be regarded at an early state of evolution. ${ }^{142}$ In this regard, for international law to be effective there needs to be a general acceptance that "international law--and the ICJ in particular--are important contributors" to international stability; this acceptance is "fundamental to the evolution of an international legal system."143 If states are to interact on the basis of lawfulness, the disputants will need to conceptualize their differences 
within a framework, or at least be willing "to fit the dispute under the control of legal machinery."144 Indeed:

It is essential that the United States government discover the practical value of legal selfrestraint and that we find lawful ways to promote our political interests.

The mere existence of law cannot itself create order in international relations, but predictability in international relations will increase if minimum degrees of law are observed--and international law may rationalize and extend whatever order exists. ${ }^{146}$ There is a need to develop policies respecting international law--for the sake of managing international security, and ultimately for survival. "Until we build a real international community, other forms of coercion will remain as instruments for the games nations play. 147

The United States as a Villain. U.S. actions in Nicaragua have weakened the prestige of the United States itself, as well as weakening inernational law. As some analysts have argued, the U.S. withdrawal from the Optional Clause made the United States seem guilty of the Nicaraguan charges. It has been argued that the U.S. withdrawal from the Court is proof that the Reagan Administration had no real facts to support its assertion of Nicaraguan involvement in El Salvador, and no justificaion for U.S. military policies. 148 Not only can the United States be portrayed as guilty in the short run, but it has also been argued that 
"in the long run, it deprives the United States of whatever moral superiority accrues from a continuous commitment to restraint and law."149 For example, the United States had historically been committed to the idea of a higher law as codified in the Declaration of Independence and the Constitution; but as a result of recent U.S. military policies the United States has even been characterized by one analyst as "becoming an outlaw in international politics." 150 According to this point of view, the United States only is concerned about international law when it is convenient for its own political purposes. For example, the United States has deplored the former government of Grenada and the Sandinista government, yet the United States tolerates human rights abuses in governments it favors, such as in Guatemala, Paraguay, or Chile. Rather than observing international legal norms, the United States can be viewed as following power-seeking motives in regard to Nicaragua: "United States 'covert' tactics are purely counter-revolutionary operations that deliberately subordinate humanitarian concerns to the presumed interests of geopolitics."15l Even members of the OAS have expressed concern about U.S. actions. In a November 1986 meeting, the Peruvian delegate asked the OAS how it was possible that the United States "an OAS member state can legally approve financing, training, and arming an irregular army to attack another country that is also a member of the same organization." 152 
OVERALL EVALUATION OF U.S. STRATEGIES

IN NICARAGUA

The historical overview of U.S. actions in Nicaragua points out the heavy reliance of the United States upon military strategies to manage political or economic uncertainty. These policies have not eradicated the sources of instability, and U.S. actions--as in support of Somoza-- have tended to support the status quo, preventing meaningful reforms in Nicaragua. Thus, in the long run, the problems causing instability have continued to fester.

In spite of American policies a Marxist/socialist government has developed which the United States has regarded with disfavor. Aside from deploring a lack of true democracy and human rights, the United States has regarded the Sandinistas as a destabilizing factor in the Caribbean Basin area. The Reagan Administration particularly tended to view developments in Nicaragua from a Cold War perspective, seeing the Sandinistas as a front for communist agitation within the region. The Reagan Administration's current approach to Nicaragua continues to rely upon military strategies--rather than exploring alternative approaches to resolution--such as through the Contadora process or through ICJ resolution.

Through its military strategies the United States has attempted to alter Nicaragua's state behavior. A variety of military strategies have been pursued in Nicaragua. For 
example, shows of force have been conducted over recent years. Large naval displays have been regarded as "gunboat diplomacy" by some analysts because the scope and size of recent maneuvers, such as Big Pine II, would suggest that they were meant to have a coercive threat. Threatening actions were backed by threatening statements from Reagan, Haig, Kirkpatrick and other top administration officials. The location of naval task forces off both coasts of Nicaragua and of U.S. troops near the Nicaraguan border could also be construed as actions designed to make the verbal threats more credible. U.S. actions have seemed to promise this. Over time, U.S. sponsored military activities have escalated. In fact, there were so many military personnel involved in the Big Pine II exercises that this has been regarded by some as no less than a temporary stationing of U.S. troops in the area. Just as there came to be military advisors and citizens involved in this area, there was also an increase in the amount of U.S. finances spent on these activities. When congressional policies were designed to restrain U.S. military strategies, secret arms deals, secret Swiss accounts, and private donations by private citizens and other foreign leaders temporarily financed the U.S. supported contra effort. United States strategies also seemed to have been used as a threat based upon the assumption that the expectation of continued violence would "get the wanted behavior." 153 However, military strategies have also been 
used as a bargaining tool. The United States has suggested that its support of the contras is designed to foster change in the Nicaraguan government; presumbly enough suitable changes by Nicaragua would affect U.S. actions, alleviating the necessity of U.S. support for the contras and their U.S. training camps.

And, if the Nicaraguans didn't change their political positions, it was hoped that the U.S. military policies would lead to the fall of the Nicaraguan government. In 1983 the CIA Director Casey predicted in congressional testimony that the contras stood a good chance of defeating the Sandinistas by the end of the year. 154 other Administration officials hoped continued covert activities would pressure the Sandinistas to infringe on civil liberties; at the least this would diminish the appeal of Nicaragua as a model for other countries to follow. 155 still other officials hoped:

...that a threatened Sandinista government will bring itself down by further repressing its internal opposition, thereby strengthening the determination of moderate forces to resist. If 15 hat happens... then the Sandinistas will fall...

To this date, U.S. military policies have not seemed very effective in achieving U.S. objectives. Nicaragua has admitted having social, economic, and political problems--but has seemed determined not to succumb to U.S. pressures. Contra activities not only have been of doubtful value, but U.S. support of the contras has been increasingly criticized, both at home and abroad. 
U.S. policies in Nicaragua need to be recalculated and alternatives to military strategies need to be explored. 


\section{ENDNOTES}

$1_{\text {For a more complete report of the Rissinger }}$ Commission's report see Cochrane, "Perspectives on the Central American Crisis," p. 755-777.

2 Barry and Preusch, p. 271.

3 Berryman, p. 12 .

${ }^{4}$ Barry and Preusch, p. 272.

${ }^{5}$ Berryman, p. 12 .

${ }^{6}$ Barry and Preusch, p. 272.

7 Dennis Gilbert, "Nicaragua," in Confronting

Revolution, eds. Morris Blackman, William M. LeoGrande, and Kenneth E. Sharpe (New York: Pantheon, 1986), p. 89.

${ }^{8}$ LaFeber, "The Burdens of the Past,", p. 49.

${ }^{9}$ Gilbert, p. 89 .

${ }^{10}$ Leiken, "Can the Cycle be Broken?" p. 5.

11 The summary of the revolution is based on

Gilbert's analysis, pp. 90-92.

12 Gilbert, p. 92 .

${ }^{13}$ Jeff M. McConnell, "Counter-revolution in

Nicaragua: the U.S. Connection," in The Nicaragua Reader, eds. Peter Rosset and John Vanderneer (New York: Grove Press, 1983), p 80 . 
${ }^{14}$ Ibid.

15 Gilbert, p. 94 .

${ }^{16}$ Ibid.

17 McConnell, p. 185.

${ }^{18}$ Gilbert, p. 99.

${ }^{19}$ Ibid.

20 Ibid.

${ }^{21}$ Ibid., p. 100 .

22 McConnell, p. 184.

${ }^{23}$ Ibid., p. 184.

${ }^{24}$ Walter LaFeber, "The Reagan Policy in Historical Perspective," in The Central American Crisis, eds. Kenneth M. Coleman and George C. Herring (Wilmington: Scholarly Resources, 1985), p. 2 .

25 McConnell, p. 184 .

26 Ibid., p. 185 .

27 Ibid.

${ }^{28}$ This discussion regarding the debate over

U.S. policies has been based upon the Richard Alan white's analysis in The Morass (New York: Harper and Row, 1984), p. 54 .

${ }^{29}$ The discussion regarding symmetry is based upon Dickey's analysis in "Central America: From Quagmire to Cauldron?", p. 663-8.

${ }^{30}$ Dickey, p. 668 .

${ }^{31}$ Dickey, p. 663 . 
32 Ibid.

${ }^{33}$ william P. Bundy, "A Portentous Year," Foreign Affairs 62(1984): 502 .

34 White, p. 65 .

${ }^{35}$ Joseph Cirincione and Leslie C. Hunter "Military Threats and Potential," in Central America, ed. Robert S. Leiken (New York: Pergamon Press, 1984).

${ }^{36}$ Dickey, pp. 664-5.

37 Ibid.

38 Ibid., p. 664 .

${ }^{39}$ White, p. 65 .

40 Ibid.

${ }^{41}$ Ibid., p. 200 .

42 Ibid., p. 200.

${ }^{43}$ Cirincione, p. 179.

${ }^{44}$ The military influence of U.S. troops is based upon Walker's analysis in "Nicaraguan-U.S. Friction: The First Four Year's 1979-1983," pp. 170-172.

${ }^{45}$ Dickey, p. 669.

${ }^{46}$ Ibid.

47ninternational Court of Justice: Case Concerning Military and Paramilitary Activities in and Against Nicaragua (Nicaraqua $v$ United States," in International Legal Materials 25(1986): 1023-1324. ${ }^{48}$ LaFeber, "The Reagan Policy in Historical Perspective," p. 1 . 
49 Arnson, p. 334.

50 Ibid.

${ }^{51}$ Volk, Steven, "Honduras: Into the Central American Mallstrom," in Revolution in Central America, ed. John Althoff. (Boulder: Westview Press, 1983), p. 126.

52 The following account is based on White's analysis in The Morass, p. 197.

${ }^{53}$ White, p. 159 .

54 Bundy, p. 502 .

${ }^{55}$ Dickey, p. 661 .

56 Ibid.

57 LaFeber, "The Reagan Policy in Historical Perspective," p. 3 .

${ }^{58}$ Ibid.

${ }^{59}$ Ibid., p. 1 .

${ }^{60}$ Viron Vaky, "Reagan's Central American Policy: An Isthmus Restored," in Central America (New York: Permagon Press, 1984), p. 249.

${ }^{61}$ Ibid., p. 250 .

62 Ibid.

${ }^{63}$ Richard Newfarmer, Introduction to From Gunboats to Diplomacy by Richard Newfarmer, ed., p. xi.

${ }^{64}$ Ibid.

${ }^{65}$ Bundy, p. 504 .

${ }^{66}$ Dickey, p. 666. 
${ }^{67}$ White, p. 201.

68 Ibid.

${ }^{69}$ Ibid.

${ }^{70}$ Leiken, "Can the Cycle be Broken?", p. 10 .

${ }^{71}$ Ibid.

${ }^{72}$ Dickey, p. 666 .

${ }^{73}$ Ibid.

74 Ibid.

$75_{\text {White, p. } 202 .}$

${ }^{76}$ Ibid., p. 201 .

77 White, p. 203.

$78^{\text {Ibid., p. } 84 .}$

${ }^{79}$ Brecher, p. 209.

${ }^{80}$ Ibid.

${ }^{81}$ Dickey, p. 669.

82 Ibid.

${ }^{83}$ Ibid.

${ }^{84}$ The information regarding U.S. involvement is

based on the material presented to the ICJ. See Nicaragua $v$ United States in International Legal Materials.

${ }^{85}$ Carlos Tunnermann, "Relations Between the United

States and Nicaragua," World Affairs Journal 5(1986): 29.

${ }^{86}$ International Legal Materials, p. 1039.

${ }^{87}$ Ibid., p. 1040 .

${ }^{88}$ Ibia.

${ }^{89}$ Ibid., p. 1043 . 
${ }^{90}$ Ibid., p. 1046.

91 Ibid., p. 1078 .

92 Ibid., p. 1047.

93 Ibid.

94 Ibid.

${ }^{95}$ Ibid., p. 1078.

96 Ibid.

97 Ibid, p. 1090.

${ }^{98}$ Ibid., p. 1083.

99 Ibid., p. 1081.

100 Ibid., p. 1090.

${ }^{101}$ Ibid., p. 1081.

102 Ibid., p. 1091.

103 Ibid.

${ }^{104}$ Marian Nash Leich, "Contemporary Practice of the United States Relating to International Law," American Journal of International Law 79(1985): 439 . ${ }^{105}$ Ibid., p. 441.

${ }^{106}$ Thomas M. Franck, "Icy Day at the ICJ," American Journal of International Law, 79(1985): 381 .

${ }^{107}$ Leich, p. 439.

${ }^{108}$ Ibid., p. 440 .

109 Julius stone, Visions of World order

(Baltimore: John Hopkins University Press, 1984), p. 132. ${ }^{110}$ Ibid.

${ }^{111}$ Craig and George, pp. 22-3. 
112 Scott, Gary L. and Craig L. Carr. "The ICJ and Compulsory Jurisdiction: The Case for closing the Clause." Portland State University.

${ }^{113}$ Leigh, Monroe, "Judicial Decisions," American Journal of International Law 79(1985): 476.

114 scott and Carr, "The ICJ and Compulsory Jurisdiction: The Case for closing the Clause," p. 25.

${ }^{115}$ Scott and Carr, "Are States Moral Agents?" p. 86. ${ }^{116}$ Franck, p. 381 .

117 Franck, p. 384 .

${ }^{118}$ Scott and Carr, "The ICJ and Compulsory Jurisdiction: The Case for Closing the clause," p. 27. 119 Franck, p. 384 .

120 Ibid.

${ }^{121}$ Anthony D'Amato, "Nicaragua and International

Law: The 'Academic' and the 'Real,'" American Journal of International Law 79(1985): 658 .

${ }^{122}$ Louis René Beres, "Becoming an Outlaw: United States Foreign Policy and Central America," International Journal 70 (1985):

${ }^{123}$ Richard Falk, Legal order in a Violent world (Princeton: Princeton University Press, 1968), p. 187. 124 James Fawcett, Law and Power in International Relations (London: Faber and Faber, 1982), p. 11. ${ }^{125}$ Ibid. 
${ }^{126}$ Tom J. Farer, "Political and Economic Coercion in Contemporary International Law," American Journal of International Law 79(1985): 409 .

127 Scott and Carr, "Are States Moral Agents?" pp. 89-90.

128

D'Amato, p. 663.

129 Ibid., p. 660 .

130 Beres, p. 510 .

${ }^{131}$ Ibid., p. 514 .

132 Ibid., p. 511 .

133 Ibid., p. 512 .

134 Ibid., p. 528 .

${ }^{135}$ Evan Luard, "Superpowers and Regional Conflicts," Foreign Affairs 64(1986): 1009 .

${ }^{136}$ Scott and Carr, "Are States Moral Agents?" p. 90. 137 Ibid.

${ }^{138}$ For a more in-depth discussion see scott and Carr, "Are States Moral Agents?"

139 Beres, p. 527.

140 Falk, p. 223.

141 Fawcett, p. 44 .

142 Ibid., pp. 13-14.

143 Scott and Carr, "The ICJ and Compulsory

Jurisdiction: The Case for closing the clause," p. 19.

144 Ibid., p. 22 .

145 Falk, p. 186 . 
146 Fawcett, p. 119.

${ }^{147}$ Farer, "Political and Economic Coercion in Contemporary International Law," p. 413.

148 Tunnerman, p. 29.

${ }^{149}$ Franck, p. 379.

${ }^{150}$ For an in-depth explanation of this point of view see Beres, "Becoming an Outlaw: United States Foreign Policy and Central America," pp. 510-529.

$151_{\text {Beres, p. } 513 .}$

${ }^{152}$ Stephen Kinzer, "At O.A.S., Many Reject the Contras," New York Times, 15 November 1986, Sec. 4, p. Y4.

${ }^{153}$ See Thomas C. Schelling, "Bargaining, Communication, and Limited War," in Power, Action, and Interaction, ed. Geroge H. Quester (Boston: Little, Brown and Co., 1971), pp.79-104.

154 White, p. 63.

155 walker, p. 171 .

156 Brecher, p. 210 . 


\section{CHAPTER $\mathrm{V}$ \\ CONCLUSIONS AND RECOMMENDATIONS}

\section{GENERALIZATIONS}

Although states have pursued order-seeking strategies at times, they have often seemed to follow advice given to the prince by Machiavelli--that force is often necessary to achieve state goals. While moralists and realists have debated over the appropriateness of force, states nevertheless have continued to employ or threaten military actions. These policies appear to have been based upon the assumption that the threat or even the use of limited violence is useful in projecting state power to alter the behavior of other states. ${ }^{1}$ Further, these military strategies have been considered more effective methods to communicate the resolve of a state than merely verbalizing state intentions. 2 In fact, many analysts have viewed military strategies as part of a communication process--as an influence, bargaining, or coercive attempt to alter the behavior of other states. ${ }^{3}$

The use of U.S. military strategies as a means to alter state behavior has been evident in the Caribbean Basin, with the United States pursuing a variety of military 
policies. Some policies have attempted to alter the behavior of other states, but to do so without engaging in physical violence. These policies include conducting naval maneuvers, as a "show-of-force" to a nearby state which the united states wished to influence, as when the Marblehead was sent to the coast of El Salvador to influence a ceasefire agree00nt. In some instances, U.S. policies have not actually involved using force against another state; but the threat of using such force has made the military policies seem coercive. For example, official statements by U.S. policymakers and large naval maneuvers such as the Big Pine II exercises seem to have been intended to threaten Nicaragua to alter its state behavior. In other instances the United States apparentiy has assumed that limited violence is useful to project state power. For example, U.S. troops intervened in Haiti in 1915 to secure strategic and economic control of the area; U.S. troops intervened in the Dominican Republic from 1916-1924, establishing martial law and a U.S. military government; and in 1917 U.S. marines intervened in Cuba, putting down strikes and protecting U.S. property. Another strategic policy of the United States has been categorized as "coercive diplomacy." United States strategy during the Cuban Missile Crisis, has been characterized as "coercive diplomacy." In spite of the high level of risk during this crisis U.S. policy has been conceptualized as "a persuasion attempt rather than pure coercion." 4 However, the Bay of 
Pigs invasion has been regarded as definitely coercive--a more "crude use of force." 5 These policies of using force suggest that the United States has viewed limited violence as useful to influence, threaten, coerce, or bargain with a country in order to alter that state's behavior.

\section{INFERENCES}

\section{First Impressions}

In the short term it might seem that the U.S. military policies in the Caribbean Basin have been successful. Such policies have been used to influence, threaten, coerce, or bargain with a country to alter its state behavior.

There are many examples to illustrate this point. For instance military strategies have enabled the United States to protect American economic interests; and the United States has remained the hegemonic power in the area. The United States has sponsored groups who successfully overthrew the Arbenz government in Guatemala; prevented a communist government from coming to power in the Dominican Republic; and halted the increased influence of the Soviets during the Cuban Missile Crisis. More recently, United States military action prevented a communist government from solidifying its political power in Grenada. Military strategies are currenty being pursued with regard to Nicaragua; and there is some evidence to indicate that Nicaragua did respond to U.S. military policies by becoming more accepting of the Contadora 
negotiation process. It plausibly could be argued that restrained Cuban and Soviet support for Nicaragua is partially due to hesitation created by U.S. military strategies.

\section{Further Analysis}

A more in-depth analysis suggests that first impressions regarding the U.S. use of force are not entirely accurate. Although many military strategies have seemed useful at the moment, these same policies have presented problems over a longer period of time.

United States military intervention has particularly been resented. As previously noted, in 1915 the United States marines imposed martial law in Haiti to ensure a stable environment; yet a growing nationalist movement opposed this action, leading to a tense political situation and to a demand for the withdrawal of U.S. troops--which was agreed to in 1934. In Panama, the United States was influential in establishing an increased military presence in the area during World War II, but U.S. actions produced "anti-Yankee nationalism." Other resentments from varied U.S. invasions have continued to affect U.S.-Caribbean relations.

There also has been a concern regarding whether a military strategy was the only policy that could have been employed. For example, senator Fulbright opposed U.S. actions in Guatemala. He argued that such a military policy 
did not represent the best foreign policy and that U.S. reliance upon military strategies prevented other political options from being chosen. This same argument has been applied to U.S. actions in Grenada and Nicaragua. And, analysts who have reviewed the Bay of pigs invasion have felt that political options were not fully explored because policymakers relied upon a previous Guatemalan covert plan which seemed applicable to the Cuban invasion.

It has also been suggested that the United States is employing military strategies to the degree that order in the international community is threatened by U.S. actions. In fact, the United States has come to be regarded by some critics as a state that only follows international law when it seems convenient for it to do so. For example, U.S. actions in the Dominican Republic were ratified after the fact by the O.A.S. Or, in the case of the Grenada invasion, the United states responded to a request from several Eastern Caribbean states, but not from a majority of states as required by the treaty. Such actions have been regarded unfavorably by the international community as demonstrated by various U.N. resolutions, speeches, and even by security council votes and debates. Allies, even in the O.A.S., criticized the United States for its actions in Grenada. The ICJ also stated that certain U.S. actions in connection with the mining of the Nicaraguan harbor were in opposition to international law. It has been argued that the United States 
further indicated its disregard for international law by refusing to allow the matter to be resolved through international legal dispute processes--claiming instead that the issue was a political matter.

Just as the United States has seemed to disregard international law, it has also seemed to bypass international organizations or regional groups which could help in dispute resolution. It has seemed--especially in the Nicaraguan case--that the United States has preferred to rely upon military strategies rather than to trust in a resolution process that it could not control. The United States has not appeared tolerant of accepting political or economic diversity within the region. For example, a previous intimation by Mexico--that it might be possible for a socialist country to peacefully exist with its neighbors as long as it made no attempt to export its revolutionary ideas--has reinforced the suspicion of the United States toward regional solutions.

\section{ASSUMPTIONS CHALLENGED}

\section{Assumption \#1}

The assumption that forceful policies are useful pragmatic strategies needs to be challenged. As noted, policies which seemed successful in the short term often caused problems in the future. It has been pointed out that these U.S. policies have caused criticism for the United states. It is difficult to accept that unpopular policies are 
U.S. actions often have disturbances within the international community. This is a particularly alarming fact. It was noted earlier that the international environment has been characterized as being anarchic, with risktaking having been a common pattern of international relations. In fact, analysts have argued that a state might weigh power-seeking or order-seeking strategies to calculate which strategy would pay the greatest dividends in any particular instance ${ }^{6}$ Yet, these same analysts have pointed out that power-seeking by one state may increase power-seeking strategies in other states. ${ }^{7}$ If, as also argued by these analysts, the state has a "moral responsibility" to manage international uncertainty in the best interests of its citizens, then it would seem the U.S. reliance upon military strategies needs to be reevaluated.

It does seem that U.S. actions have created more uncertainty within the international community. It has been noted that previously accepted patterns of interaction have become less clear due to U.S. military strategies. For example, recent U.S. support of the contras has suggested that other states could claim they were intervening to change a repressive government. "Backyards" or spheres of influence seem to be less clearly deliniated--with the U.S. aiding Afghanistan rebels; the U.S.S.R. aiding the Sandinistas. Therefore, it is not clear that military strategies are 
useful over a long period of time if they significantly increase the international uncertainty in the world.

\section{Assumption \#2}

The assumption that forceful military strategies can be designed in a calculated, carefully designed manner to influence, bargain or coerce also needs to be reconsidered. As evidenced by the historical case studies, neither the success nor the possible failures of policies can be absolutely forseen. During the Cuban Missile Crisis, the potential for serious escalation certainly existed as the Soviet ships approached the U.S.-established naval quarantine line. The Bay of Pigs invasion also involved the potential for increasing international uncertainty. After the unsuccessful invasion attempt, the possibility for escalation existed. For example, United States policymakers could have pursued guerilla warfare in Cuba. Currently, the U.S. support of the contras risks widening the conflict in the Caribbean area.

The various case studies have suggested that there is no guarantee a military policy will have a particular effect. As Bernholz has pointed out: the international system is not perfectly predictable or fully controllable. 8 Therefore, military strategies represent serious risks and increase international uncertainty. As Etheredge has argued: 
"...analytical brilliance and technical rationality are neither necessary nor sufficient conditions for peace." 9

Furthermore, present American foreign policies ignore changes in the international system which have markedly diminished the ability of the United States to control events:

Power to control, or even to dictate, internal political processes within Latin American nations has been weakened irreversibly by the natural historical processes of growth, the integration of nation-states on the continent, and the release of pent-up political, social and economic aspiprations of the vast majority of the populations in many of these countries. The time has long passed when the United States could cavalierly send tropps to install regimes of its own liking.

\section{RECOMMENDATIONS}

The United States foreign policy needs to stress the development of policies rather than heavily relying upon military actions. Since it would seem that U.S. strategies often have been dysfunctional rather than utilitarian, the United states needs to recalculate its policies, devising state behaviors that will not only obtain short-term goals but which will be effective over a longer period of time. Analysts have suggested a wide variety of alternatives to current American policies. It has been suggested that observing international law and pursuing other order-seeking behaviors could "do much to counteract the uncertainty" 
associated with power-seeking. 11 other analysts have stressed the poverty and instability of the Caribbean area; and have suggested that U.S. supported reform efforts could create a more economically well balanced--possibly a more democratic--environment which could create more stability in the area. Still others have suggested that the United States needs to re-evaluate its stated reasons for intervention. Perhaps the verbalized assumption that communism is dangerous to U.S. security needs to be re-calculated; perhaps the United States needs to be more accepting of socialist regimes in the Caribbean as long as they do not try to foment revolution in other areas.

Regardless of the specific policies devised, it is clear that to manage international uncertainty in the best interests of its citizens, the United States needs to pursue alternative strategies. The warning suggested by this study is clear: "Long term success in the application of military strategies is not easily achieved; disaster is always a single bad decision away." 12

Further, as has been pointed out, a substantial degree of general consent is needed in the international system. "The exercise of power alone cannot lead to a stable international order. "13 


\section{ENDNOTES}

${ }^{1}$ see for example, Thomas c. Schelling, "The Diplomacy of Violence," in The Use of Force, ed. Robert J. Art and Renneth N. Waltz (Boston: Little, Brown and Co., 1971), pp. 76-99.

${ }^{2}$ see for example Thomas C. Schelling, Arms and Influence, p. 150 or Oran Young, The Politics of Force, pp. 117-118.

${ }^{3}$ Craig and George, p. 123.

${ }^{4}$ Ibid., 189.

5 Ibid.

${ }^{6}$ See for example, Scott and Carr, "Are States Moral Agents?"

7 Ibid., p. 96 .

8 Bernholz, p. 15.

${ }^{9}$ Etheredge, p. 200.

10 McCall, p. 32 .

${ }^{11}$ Scott and Carr, "Are States Moral Agents?" p. 90. ${ }^{12}$ Craig and George, p. 193.

${ }^{13}$ Crawford and Lenway, p. 13. 
SOURCES CONSULTED

Allison, Graham T. "Conceptual Models and the Cuban Missile Crisis." American Political Science Review

63 (September 1969): 689-718.

Arnson, Cynthia. "Background Information on El Salvador and U.S. Military Assistance to Central America." in Revolution in Central America, pp. 328-336. Edited by John Althoff. Boulder: Westview Press, 1983 .

Arnson, Cynthia. El Salvador. Washington, D.C.: Institute for Policy Studies, 1982.

Aron, Raymond. "The Evolution of Modern Strategic Thought." In Problems of Modern Strategy, pp. 12-20. New York: Praeger for the Institute for Strategic Studies, 1970.

Art, Robert J. and Waltz, Kenneth N. "Technology, Strategy, and the Uses of Force." In The Use of Force, pp. 1-25. Edited by Robert J. Art and Renneth $N$. Waltz. Boston: Little,Brown and Co., 1971.

Baker, Russell. "The Usefulness of Certain Rinds of Force." In The Theory and Practice of International Relations, 346-348. 3rd ed. Edited by Fred A. Sonderman, William C. Olson, and David S. McLellan. Englewood Cliffs: Prentice-Hall, 1970.

Barry, Tom and Preusch, Deb. The Central America Fact Book. New York: Grove Press, 1986.

Baylis, John, et al., Contemporary Strategy. New York: Holmes and Meier, 1975.

Beres, Louis René. "Becoming an Outlaw: United States Foreign Policy and Central America." International Journal 70(1985): 510-529.

Bernholz, Peter. The International Game of Power. Berlin: Mouton, 1985 .

Berryman, Phillip. Inside Central America. New York: Pantheon, 1985. 
Blachman, Morris $J$; Bennett, Douglas C.; LeoGrande, William M; and Sharpe, Renneth E. "The Failure of the Hegemonic Strategic vision. In Confronting Revolution, pp. 329-350. Edited by Morris J. Blachman, William M. LeoGrande, and Renneth E. Sharpe. New York: Pantheon, 1986 .

Blachman, Morris J. and Sharpe, Renneth. "El Salvador: The Policy That Failed." In From Gunboats to Diplomacy, pp. 72-88. Edited by Richard Newfarmer, Baltimore: Johns Hopkins Univeristy Press, 1984.

Bloomfield, Lincoln P. "Patterns of American Intervention." In The Theory and Practice of International Relations, pp. 322-331. 3rd ed. Edited by Fred A. Sondermann, William C. Olson, and David S. McLellan. Englewood Cliffs: Prentice-Hall, 1970.

Bossert, Thomas John. "Panama." In Confronting Revolution, pp. 183-205. Edited by Morris J. Blachman, William M. LeoGrande, and Renneth E. Sharpe. New York: Pantheon, 1986 .

Brecher, John. "A Secret War for Nicaragua." In The Nicaraqua Reader, pp. 208-215. Edited by Peter Rosset and John Vanderneer. New York: Grove Press, 1983 .

Briggs, Herbert w. "Nicaraqua v. United States: Jurisdiction and Admissibility." American Journal of Law 79(1985) 373-378.

Brzezkinski, zbigniew. Power and Principle. New York: Farrar, straus, Giroux, 1983.

Bundy, William P. "A Portentous Year." Foreign Affairs $62(1983-4): 485-520$.

Carr, E. H. "The Twenty Years' Crisis." In Contemporary Theory in International Relations, pp. 254-273. Edited by Stanley Hoffman. Englewood Cliffs: Prentice-Hall, 1960.

Carr, E.H. "Military Power." In The Theory and Practice of International Relations, 171-172. 3rd ed. Edited by Fred A. Sonderman, william $C$. Olson, and Dvid S. McLellan. Englewood Cliffs: Prentice-Hall, 1970. 
Cirincione, Joseph and Hunter, Leslie C. Military Threats, Actual and Potential." In Central America, pp. 173-192. Edited by Robert S. Leiken. New York: Pergamon Press, 1984.

Cochrane, James D. "Perspectives on the Central American Crisis." International Organization $39(1985):$ 755-777.

Coleman, Kenneth M. "The Consequences of Excluding Reformists from Power." In The Central American Crisis, pp. 73-96. Edited by Kenneth Coleman and George $C$. Herring. Wilmington: Scholarly Resources, 1985.

Collier, Simon; Harold Blakemore, and Skidmore, Thomas E. eds. The Cambridge Encyclopedia of Latin America and the Caribbean. Cambridge: Cambridge University Press, 1985 .

Craig, Gordon A., and George, Alexander L. Force and Statecraft. New York: Oxford University Press, 1983 .

Crawford, Beverly and Lenway, Stefanie. "Decision Modes and International Regime Change: Eastern Collaboration on East-West Trade." World Politics 37(1984-5): 373-402.

D'Amato, Anthony. "Nicaraqua and International Law: The 'Academic' and the 'Real.'" American Journal of International Law 79(1985): 657-663.

Destler, I.M. "The Elusive Consensus: Congress and Central America." In Central America, pp. 319-336. Edited by Robert S. Leiken. New York: Permagon Press, 1984.

Deutsch, Karl $w$. The Analysis of International Relations. Englewood Cliffs: Prentice-Hall, 1968.

Deutsch, Rarl w. "On the Concepts of Politics and Power." In The Theory and Practice of International Relations, 81-88. 3rd ed. Edited by Fred A. Sondermann, William C. Olson, and David S. McLellan. Englewood Cliffs: Prentice Hall, 1970.

Dewalt, Billie R. "The Agrarian Bases of Conflict in Central America" In The Central American Crisis, pp. 43-54. Edited by Kenneth M. Coleman and George C. Herring. Wilmington: Scholarly Resources Inc., 1985. 
Dickey, Christopher. "Central America: From Quagmire to Cauldron?" Foreign Affairs 62(1983-4): 659-695.

Etheredge, Lloyd. Can Governments Learn? New York: Pergamon Press, 1985.

Fagen, Richard R. and wayne A. Cornelius, Jr., eds. Political power in Latin America: Seven Confrontations. Englewood Cliffs: Prentice-Hall, Inc., 1970 .

Falk, Richard. Legal order in a Violent World. Princeton: Princeton Unversity Press, 1968.

Farer, Tom J. "At Sea in Central America: Can We Negotiate Our Way to Shore?" In Central America, pp. 279-298. Edited by Robert $S$. Leiken. New York: Permagon Press, 1984 .

Farer, Tom J. "Contadora: The Hidden Agenda." Foreign Policy 59(1985): 59-72.

Farer, Tom J. "Political and Economic Coercion in Contemporary International Law." American Journal of International Law 79(1985): 405-413.

Fawcett, James. Law and Power in International Relations. London: Faber and Faber, 1982.

Feinberg, Richard E. and Newfarmer, Richard. "The Caribbean Basin Initiative: Bold Plan or Empty Promise?" In From Gunboats to Diplomacy, pp. 210-227. Edited by Richard Newfarmer. Baltimore: The Johns Hopkins Press, 1984.

Franck, Thomas M. "Icy Day at the ICJ." American Journal of International Law 79(1985): 379-384.

Frei, Daniel, ed. Managing International Crisis. Beverly Hills: Sage Publications, 1982 .

George, Alexander L.; Hall, David K. and Simons, William E. The Limits of Coercive Diplomacy. Boston: Little, Brown and Co., 1971.

George, Alexander L. and Smoke, Richard. Deterrence in American Foreign Policy: Theory and Practice. New York: Columbia University Press, 1974. 
Gilbert, Dennis. "Nicaragua." In Confronting Revolution, pp. 88-124. Edited by Morris J. Blachman, William M. LeoGrande, and Kenneth E. Sharpe. New York: Pantheon, 1986.

Goulet, Denis. "Is Gradualism Dead? Reflections on Order, Change, and Force." In Moral Dimensions of American Foreign Policy, pp. 315-348. Edited by Kenneth $W$. Thompson. New Brunswick: Transaction Books, 1984.

Gray, Colin S. Strategic Studies and Public Policy. Lexington: University Press of Rentucky, 1982.

"Grenada." U.N. Chronicle 21(1984): 4-8.

Halpern, Manfred. "The Morality and Politics of Intervention." In Moral Dimensions of "American Foreign Policy, pp. 75-104. Edited by Renneth W. Thompson. New Brunswick: Transaction Books, 1984.

Handel, Michael. Weak States in the International system. Totowa, N.J.: Frank Cass, 1981.

Herring, George C. and Coleman, Kenneth M. "Beyond Hegemony: Toward a New Central American Policy." In The Central American Crisis, pp. 219-228. wilmington: Scholarly Resources, 1985.

Hoffman, Stanley. Dead Ends. Cambridge: Ballinger Publishing Co., 1983.

Howard, Michael. "The Classical Strategists." In Problems of Modern Strategy, pp. 45-53. New York: Praeger for the Institute for Strategic studies, 1970.

Hunter, Leslie and Cirincione, Joseph. "Military Threats, Actual and Potential." In Central America, pp. 173-192. Edited by Robert S. Leiken. New York: Permagon Press, 1984 .

"International Court of Justice: Case Concerning Military and Paramilitary Activities in and Against Nicaragua (Nicaragua $v$. United States) " International Legal Materials 25(1986): 1023-1324.

Johnson, Robert. "Escalation Then and Now." Foreign Policy 60(1985): 130-147. 
Karl, Terry. "Mexico, Venezuela, and the Contadora

Initiative." In Confronting Revolutions,

pp. 271-294. Editd by Morris J. Blachman, William M. LeoGrande, and Kenneth E. Sharpe. New York:

Pantheon, 1986 .

Kenworthy, Eldon. "Central America: Beyond the Credibility Trap." In The Central Ameican Crisis, pp. 111-136. Edited by Kenneth M. Coleman and George C. Herring. wilmington: Scholarly Resources, 1985.

Kinzer, Stephen. "At O.A.S., Many Reject the Contras," New York Times, 15 November 1986, Sec. 4, p. Y4.

Kissinger, Henry A. "The Problems of Limited War." In The Use of Force, pp. 99-115. Edited by Robert J. Art and Kenneth N. Waltz. Boston: Little, Brown and Co., 1971.

Kurtz, James R. "The New Realism in U.S.-Latin American Relations: Principles for a New U.S. Foreign Policy." In From Gunboats to Diplomacy, pp. 3-14. Edited by Richard Newfarmer. Baltimore: The John Hopkins University Press, 1984.

LaFeber, walter. "The Burdens of the Past." In Central America, pp. 49-68. Edited by Robert S. Leiken. New York: Pergamon Press, 1984.

LaFeber, Walter. "The Reagan Policy in Historical Perspective." In The Central American Crisis, pp. 1-18. Ed. Kenneth M. Coleman and George C. Herring. wilmington: Scholarly Resources, Inc., 1985 .

Lamborn, Alan C. "Risk and Foreign Policy Choice." International Studies Quarterly 29(1985): 385-409.

Leich, Marian Nash. "Contemporary Practice of the United States Relating to International Law." American Journal of International Law 79(1985): 431-441.

Leigh, Monroe. "Judicial Decisions." American Journal of International Law 79(1985): 442-462.

Leiken, Robert $S$. "Can the Cycle Be Broken? In Central America, pp. 3-32. Edited by Robert S. Leiken, New York: Pergamon Press, 1984. 
LeoGrande, William M.; Bennett, Douglas C.; Blachman, Morris J., and Sharpe, Kenneth D. "Grappling With Central America: From Carter to Reagan." In Confronting Revolution, pp. 295-328. Edited by Morris Blachman, William M. Leogrande, and Renneth E. Sharpe. New York: Pantheon, 1986.

LeoGrande, William M. "Cuba: Going to the Source." In From Gunboats to Diplomacy, pp. 135-146. Edited by Richard Newfarmer. Baltimore: The John Hopkins Press, 1984. 135-146.

Levy, Jack S. "Misperception and the Causes of War: Theoretical Linkages and Analytical Problems." World Politics 36(1984): 76-99.

Lewis, Gordon R. Main Currents in Caribbean Thought. Baltimore: John Hopkins University Press, 1983.

Lovell, John P. "Lessons' of U.S. Military Involvement: Preliminary Conceptualization." In Foreign Policy Decision Making, pp. 129-157. Edited by Steve Chan and Donald A. Sylvan. New York: Praeger, 1984 .

Lowenthal, Abraham. "The United States and Central America: Reflections on the Rissinger Commission Report." In The Central American Crisis, pp. 205-215. Edited by Kenneth M. Coleman and George C. Herring. Wilmington: Scholarly Resources, 1985.

Luard, Evan. "Superpowers and Regional Conflicts." Foreign Affairs 64(1986): 1006-1025.

Lukov, Vadim. "International Negotiations of the 1980s: Features, Problems and Prospects." Negotiation Journal 1(1985): 139-148.

McCall, Richard. "From Monroe to Reagan: An Overview of U.S.-Latin American Relations." In From Gunboats to Diplomacy, pp. 15-34. Edited by Richard Newfarmer. Baltimore: The John Hopkins University Press, 1984 .

McConnell, Jeff M. "Counter-revolution in Nicaragua: the U.S. Connection." In The Nicaragua Reader, pp. 175-189. Edited by Peter Rosset and John Vanderneer. New York: Grove Press, 1983.

Machiavelli, Niccolo. The Prince. Trans. W.K. Marriott. London: J. M. Dent and Sons Ltd., 1908. 
Mandel, Robert. "The Effectiveness of Gunboat Diplomacy." International Studies Quarterly 30(1986): 59-76.

Mattos, Carlos deMeira; Seignious II, George M.; Train II, Harry D.; and Tovar, Alvara Valencia. "Security in the Western Hemisphere." Atlantic Community Quarterly 22(1985): $360-366$.

Maynes, Charles William. "Logic, Bribes and Threats." Foreign Policy 60(1985): 111-129.

Millett, Richard L. "Honduras: An Emerging Dilemna." In From Gunboats to Diplomacy, pp. 89-101. Edited by Richard Newfarmer. Baltimore: The Johns Hopkins University Press, 1984.

Millet, Richard. "Praetorians or Patriots? The Central American Military." In Central America, pp. 69-94. Edited by Robert S. Leiken. New York: Pergamon Press, 1984 .

Mitchell, C.R. Structure of International Conflict. New York: St. Martin's Press, 1981.

Morgenthau, Hans. "Politics Among Nations." In Contemporary Theory in International Relations, pp. 54-73. Edited by Stanley Hoffman. Englewood cliffs: Prentice-Hall, 1960.

Neiburg, Harold L. "Uses of Violence." In The Theory and Practice of International Relations, pp. 343-346. 3rd ed. Edited by Fred $A$. Sonderman, william C. Olson, and David S. McLellan. Englewood Cliffs: Prentice-Hall, 1970 .

Newfarmer, Richard. "Introduction." In From Gunboats to Diplomacy, p xi. Edited by Richard Newfarmer, Baltimore: Johns Hopkins University Press, 1984.

"Obervations on the International Court of Justice's November 26, 1984 Judgment on Jurisdiction and Admissibility in the Case of Nicaragua v. United States of America." American Journal of International Law 79(1985): 423-430.

Oduber, Daniel. "Is Peace Possible in Central America?" In The Central American Crisis, pp. 193-204. Edited by Kenneth M. Coleman and George C. Herring. Wilmington: Scholarly Resources, 1985. 
Pastor, Robert A. "Explaining U.S. Policy Toward the Caribbean Basin: Fixed and Emerging Images." Review Article. World Politics 38(1986): 483-515.

Payne, Anthony. The International Crisis in the Caribbean. Baltimore: John Hopkins University Press, 1984 .

Payne, Anthony. "Whither CARICOM?" International Journal 40(1985): 207-220.

Pearce, Jenny. Under the Eagle: U.S. Intervention in Central America and the Caribbean. Boston: South End Press, 1982 .

Quester, George H., ed. Power, Action and Interaction. Boston: Little, Brown and Co., 1971.

Quigley, Revin. "A Framework for Evaluating the Legality of the United States Intervention in Nicaragua." Journal of International Law and Politics 71(1984): 155-186.

Ronning, c. Neale, ed. Intervention in Latin America. New York: Alfred A. Knopf, 1970 .

Rosati, Jerel A. "The Impact of Beliefs on Behavior: The Foreign Policy of the Carter Administration." In Foreign Policy Decision Making, pp. 158-191. Edited by Donald $A$. Sylvan and Steve Chan. New York: Praeger, 1984 .

Ross, David F. "The Caribbean Basin Initiative: Threat or Promise?" In The Central American Crisis, pp. 137-156. Edited by Kenneth M. Coleman and Geoge C. Herring. Wilmington: Scholarly Resources, 1985 .

Rostow, Eugene V. Law, Power and the Pursuit of Peace. Lincoln: University of Nebraska Press, 1968.

Rubin, Barry. "Reagan Administration Policymaking and Central America." In Central America, pp. 299-318. Edited by Robert S. Leiken. New York: Permagon Press, 1984.

Russett, Bruce and Starr, Harvey. World Politics. San Francisco: W. H. Freeman and Co., 1981.

Schelling, Thoams C. Arms and Influence. New Haven: Yale University Press, 1966. 
Schelling, Thomas C. "Bargaining, Communication and Limited War." In Power, Action, and Interaction, pp. 79-104. Edited by George H. Quester. Boston: Little, Brown and Co., 1971.

Schelling, Thomas $C$. "The Diplomacy of Violence." In The Use of Force, pp. 76-99. Edited by Robert J. Art and Renneth N. Waltz. Boston: Little, Brown and Co., 1971 .

Schelling, Thomas $C$. The Strategy of Conflict. Cambridge: Havard University Press, 1963.

Schoultz, Lars. "Nicaragua: The United States Confronts a Revolution." In From Gunboats to Diplomacy, pp. 116-134. Edited by Richard Newfarmer. Baltimore: The Johns Hopkins Press, 1984.

Schwarzenberger, Georg. Power Politics. New York: Praeger, 1964 .

Scott, Gary L. and Craig L. Carr. "The ICJ and Compulsory Jurisdiction: The Case for closing the clause." Portland State. Manuscript.

Scott, Gary L. and Carr, Craig L. "Are States Moral Agents?" Social Theory and Practice 12(1986): 75-102.

Serfaty, Simon. American Foreign Policy in a Hostile World. New York: Praeger, 1984 .

Sequeira, Arturo Cruz. "The Origins of Sandinista Foreign Policy." In Central America, pp. 95-110. Edited by Robert $S$. Leiken. New York: Pergamon Press, 1984 .

Sharpe, Renneth E; Bennett, Douglas C; Blachman, Morris J.; and LeoGrande, William M. "Security Through Diplomacy: A Policy of Principled Realism." In Confronting Revolution, pp. 351-368. Edited by Morris J. Blachman, William M. LeoGrande, and Renneth E. Sharpe. New York: Pentheon, 1986.

sims, Richard and Anderson, James. "The Caribbean Strategic Vacuum." In Conflict studies. No. 121. London: Institute for the Study of Conflict, 1980. 
Singer, J. David. "The Capacity to Influence." Fred A. Sondermann, William C. Olson, and David S. McLellan. In The Theory and Practice of International

Relations, pp. 218-231. 3rd ed. Englewood Cliffs: Prentice-Hall, 1970.

Smith, Peter H. "Mexico: The Continuing Quest for a Policy." In From Gunboats to Diplomacy, pp. 37-53. Edited by Richard Newfarmer. Baltimore: The Johns Hopkins University Press, 1984.

Smith, Peter. "The Origins of Crisis." In Confronting Revolution, pp. 3-22. Edited by Morris J. Blachman, William M. LeoGrande, and Kenneth E. Sharpe. New York: Pantheon, 1986.

Snidal, Duncan. "The Limits of Hegemonic Stability Theory." International Organization 39(1985): 579-614.

Stone, Julius. Visions of World order. Baltimore: Johns Hopkins University Press, 1984.

Sullivan, Michael P. International Relations: Theories and Evidence. Englewood Cliffs: Prentice Hall, 1976.

Thompson, Kenneth W., ed. Moral Dimensions of American Foreign Policy. New Brunswick: Transaction Books, 1984 .

Trudeau, Robert H. "Guatemala: The Long-Term Costs of Short-Term Stability." In From Gunboats to Diplomacy, pp. 54-71. Edited by Richard Newfarmer. Baltimore: The Johns Hopkins University Press, 1984.

Trudeau, Robert and Schoultz, Lars. "Guatemala." In Confronting Revolution, pp. 23-49. Edited by Morris J. Blachman, William M. LeoGrande, and Kenneth E. Sharpe, New York: Pantheon, 1986.

Tunnermann, Carlos. "Relations Between the United States and Nicaragua." World Affairs Journal 5(1986): $26-32$.

Vaky, Viron. "Reagan's Central American Policy: An Isthmus Restored." In Central America, pp. 233-258. Edited by Robert $S$. Leiken. New York: Permagon Press, 1984. 
Volk, Steven. "Honduras: Into the Central American Maelstrom." In Revolution in Central America, pp. 123-126. Edited by John Althoff. Boulder: Westview Press, 1983.

Vonglahn, Gerhard. Law Among Nations. 3rd ed. New York: Macmillan Publishing Co., 1976.

Walker, Thomas w. "Nicaraguan-U.S. Friction: The First Four Years, 1979-1983." In The Central American Crisis, pp. 157-192. Edited by Kenneth M. Coleman and George C. Herring. Wilmington: Scholarly Resources, 1985.

"Western Interests and U.S. Policy Options in the Caribbean Basin." Atlantic Council Paper. Atlantic Community Quarterly 21(1983-4): 356-367.

White, Richard Alan. The Morass. New York: Harper and Row, 1984 .

Wiarda, Howard J. "At the Root of the Problem: Conceptual Failures in U.S. Central American Relations." In Central America, pp. 259-279. Edited by Robert S. Leiken. New York: Permagon Press, 1984.

Wolfers, Arnold. "The Anglo-American Tradition in Foreign Affairs." In Contemporary Theory in International

Relations, pp. 240-254. Edited by Stanley Hoffman. Englewood Cliffs: Prentice-Hall, 1960.

Wolfers, Arnold. "The Goals of Foreign Policy." In The Theory and Practice of International Relations, pp. 194-198. 3rd ed. Edited by Fred A. Sonderman, William C. Olson, and David S. McLellan, Englewood Cliffs: Prentice-Hall, 1970.

Wolfers, Arnold. "Statesmanship and Moral Choice." In Contemporary Theory in International Relations, pp. 273-286. Edited by Stanley Hoffman. Englewood Cliffs: Prentice-Hall, 1960.

Wyden, Peter. Bay of Pigs. New York: Simon and Schuster, 1979.

Young, Oran R. Bargaining. Urbana: University of Illinois Press, 1975.

Young, Oran R. The Politics of Force. Princeton: Princeton University Press, 1968. 
Young, Oran R. "Strategic Interaction and Bargaining." In Bargaining, pp. 3-22. Edited by Oran R. Young . Urbana: University of Illinois Press, 1975.

Ziegler, David w. War, Peace and International Politics. 2nd ed. Boston: Little, Brown and Company, 1981. 